\title{
REVIEW
}

Open Access

\section{Exploring different methods to evaluate the impact of basic income interventions: a systematic review}

Andrew D. Pinto ${ }^{1,2,3,4^{*}}$ D, Melissa Perri ${ }^{1,4}$, Cheryl L. Pedersen ${ }^{1}$, Tatiana Aratangy ${ }^{1}$, Ayu Pinky Hapsari ${ }^{1}$ and Stephen W. Hwang ${ }^{1,4,5}$

\begin{abstract}
Background: Persistent income inequality, the increase in precarious employment, the inadequacy of many welfare systems, and economic impact of the COVID-19 pandemic have increased interest in Basic Income (BI) interventions. Ensuring that social interventions, such as Bl, are evaluated appropriately is key to ensuring their overall effectiveness. This systematic review therefore aims to report on available methods and domains of assessment, which have been used to evaluate Bl interventions. These findings will assist in informing future program and research development and implementation.

Methods: Studies were identified through systematic searches of the indexed and grey literature (Databases included: Scopus, Embase, Medline, CINAHL, Web of Science, ProQuest databases, EBSCOhost Research Databases, and PsycINFO), hand-searching reference lists of included studies, and recommendations from experts. Citations were independently reviewed by two study team members. We included studies that reported on methods used to evaluate the impact of $\mathrm{Bl}$, incorporated primary data from an observational or experimental study, or were a protocol for a future Bl study. We extracted information on the Bl intervention, context and evaluation method.

Results: 86 eligible articles reported on 10 distinct BI interventions from the last six decades. Workforce participation was the most common outcome of interest among Bl evaluations in the 1960-1980 era. During the 2000s, studies of Bl expanded to include outcomes related to health, educational attainment, housing and other key facets of life impacted by individuals' income. Many BI interventions were tested in randomized controlled trials with data collected through surveys at multiple time points.
\end{abstract}

\footnotetext{
* Correspondence: andrew.pinto@utoronto.ca

'MAP Centre for Urban Health Solutions, Li Ka Shing Knowledge Institute, Unity Health Toronto, Toronto, Canada

2Department of Family and Community Medicine, St. Michael's Hospital, Toronto, Canada

Full list of author information is available at the end of the article
}

(c) The Author(s). 2021 Open Access This article is licensed under a Creative Commons Attribution 4.0 International License, which permits use, sharing, adaptation, distribution and reproduction in any medium or format, as long as you give appropriate credit to the original author(s) and the source, provide a link to the Creative Commons licence, and indicate if changes were made. The images or other third party material in this article are included in the article's Creative Commons licence, unless indicated otherwise in a credit line to the material. If material is not included in the article's Creative Commons licence and your intended use is not permitted by statutory regulation or exceeds the permitted use, you will need to obtain permission directly from the copyright holder. To view a copy of this licence, visit http://creativecommons.org/licenses/by/4.0/ The Creative Commons Public Domain Dedication waiver (http://creativecommons.org/publicdomain/zero/1.0/) applies to the data made available in this article, unless otherwise stated in a credit line to the data. 
Conclusions: Over the last two decades, the assessment of the impact of BI interventions has evolved to include a wide array of outcomes. This shift in evaluation outcomes reflects the current hypothesis that investing in $\mathrm{Bl}$ can result in lower spending on health and social care. Methods of evaluation ranged but emphasized the use of randomization, surveys, and existing data sources (i.e., administrative data). Our findings can inform future BI intervention studies and interventions by providing an overview of how previous $\mathrm{Bl}$ interventions have been evaluated and commenting on the effectiveness of these methods.

Registration: This systematic review was registered with PROSPERO (CRD 42016051218).

Keywords: Basic income, Income inequality, Social determinants of health, Methodology, Health, Equity.

\section{Background}

Income inequality has risen in many high-income countries since the 1970s, resulting in many individuals not benefiting from the increase in societal wealth creation. Comparatively, poverty rates have remained high in many low- and middle-income countries [1-3]. Current welfare policies around the world do not adequately protect members of society, particularly during times of financial crisis [4]. Even in high income countries such as Canada, the United States, and the United Kingdom, many argue that the existing welfare policies are discriminatory and perpetuate system-level barriers for marginalized populations. Some examples of these barriers include the complicated and time-consuming bureaucracy processes to access the services, extensive policing on benefit eligibility, and the prioritization of monetary values that neglect the client's morale and quality of life [4-6].

One proposal to improve income security and reduce the onerous nature of welfare is a basic income (BI), also referred to as Universal Basic Income, Guaranteed Minimum Income, Basic Income Guarantee, negative income tax (NIT) or a demogrant [7, 8]. A $\mathrm{BI}$ is given to all who meet the income eligibility criteria, is simple to administer, and is unconditional in nature (i.e. does not require recipients to seek work) [9]. The idea of providing all members of society a BI dates back to ancient times and represents a payment from the government to ensure recipients achieve a minimum income level [10-12].

The idea of a BI gained popularity in the 1960s and 1970s, inspiring field experiments in the United States and Canada [10]. However, the neoliberal era of the 1980s and 1990s was associated with reductions in government spending and a decline in financial supports for those who were unemployed or disabled [13-15]. Within the past decade, growing income insecurity, precarious employment, and concern around displacement of manual labour by automation and artificial intelligence have sparked a renewed interest in BI $[16,17]$. The dialogue around BI further gained momentum during the COVID-19 pandemic in 2020, that resulted in a rapid loss of employment, the rise of income inequality, and substantial economic uncertainty [18-20]. To reduce COVID-19 transmission, many countries enacted lockdowns that led to business closures and worsening economic conditions $[21,22]$. Several high-income countries, such as Canada and New Zealand, have moved to provide some form of emergency income support to assist their citizens who are financially impacted by the pandemic [23, 24]. However, many argue that these temporary benefits will not be able to sustainably address the widespread and long-term impact of COVID-19 [25, 26]. Instead, a permanent BI can be explored as a potential solution to reduce this gap and bring positive impacts to various aspects of people's lives, including their health and overall quality of lives [27]. Some proponents of BI also suggested BI as a potential next step in the evolution of social welfare [28]. Further, the similarities between $\mathrm{BI}$ and some policy measures implemented during the pandemic have presented a unique opportunity to study the effect of BI policies on different life domains [26].

One of the most compelling reasons for investing in $\mathrm{BI}$ is that it may produce cost savings through reduced health and social service costs $[29,30]$. This rationale is supported by numerous studies that found a correlation between low income, worse health outcomes, and higher use of the health care system [31, 32]. In the Canadian BI field experiment (1974-1979), research suggested that receiving BI was associated with reduced hospitalizations, physician visits and some improvements in mental health [10].

Academics have long been interested in studying the impact of BI interventions on various social, health and labour-specific outcomes. The COVID-19 pandemic has also spurred further interest in the exploration of $\mathrm{BI}$ as part of post COVID-19 economic recovery plans and as a potential long-term solution to reduce the poverty rate [33]. Relevant experiments have occurred worldwide before the pandemic, in locations such as Namibia (20082010), India (2011-2012), Kenya (2011-2013) and Finland (2017-2018). However, no synthesis has been done that consolidates methods of evaluation across BI specific outcomes. Our objective was to search peer- 
reviewed and grey literature to identify and examine methods used to evaluate the impact of BI interventions. Specifically, this review provides a repository of BI evaluation methods, including study design, data collection methods, and outcome domains that can be adopted by researchers and policy makers who wish to implement a BI intervention. This review also identifies outcome domains that were overlooked in existing BI evaluations. Finally, heterogeneity in the approaches to data analysis and important considerations around BI implementation are described.

\section{Methods}

\section{Search strategy and selection criteria}

Relevant articles published on or before January 30, 2020 were searched from the following databases: Scopus, Embase, Medline, CINAHL, Web of Science, ProQuest databases, EBSCOhost Research Databases, and PsycINFO. The start year of the publication was not specified to filter the search results. To supplement searches of the indexed literature, grey literature sources were searched in consultation with an Information Specialist (Additional File 1). The following search terms were used in all of the databases: "basic income", "guaranteed annual income", "guaranteed minimum income", "minimum income", "negative income tax", "optimal income transfer", mincome, demogrant", "citizen" income", or "universal income". We also searched Google, Google Scholar, Open Grey and Campbell Library along with websites that focused on BI interventions. Additional studies were identified through expert contacts and the reference list of included studies.

Studies had to meet all three of the following inclusion criteria: 1) The article had to report on a BI intervention or program, which provided guaranteed income unconditionally to low-income individuals. Studies describing selective interventions, such as the Bolsa Familia or universal interventions in regions such as the Netherlands, were excluded due to pre-defined conditional requirements to gaining income [34]. 2) The study had to report on the methods used to evaluate the impact of BI interventions. Reporting on the methods used to implement a basic income scheme was not sufficient for inclusion. 3) The article had to report primary data from an observational study (e.g., case-control, cohort), experimental study (e.g., randomized controlled trial or RCT), or protocol for future research. Reviews, opinions, commentaries and editorials, or literature that specifically focused on a subset of the population (e.g., children, seniors) were excluded.

\section{Data extraction, synthesis and presentation}

Articles that were identified through the search were uploaded to two systematic literature review software:
Covidence and DistillerSR. Each citation was reviewed independently by two team members. Citations that were potentially relevant were retrieved for full-text review by two team members. The authors were contacted for papers that could not be retrieved. The search was not limited by language. Studies that were not available in English were reviewed by an individual fluent in the appropriate language and/or translated into English. Any disagreements on whether to include or exclude an article in each stage of screening were resolved by the project coordinator and the principal investigator (ADP).

Data from included papers was extracted by one team member and then confirmed by a second team member. The extraction form was created using MS Excel and included the following variables: citation; purpose; methods used (including type of study, type of BI implemented, dates, data collection methods, evaluation methods, data analysis methods); location; sample; participant demographics; outcome domains; and results. Data was subsequently synthesized by examining common patterns surrounding the methods of data collection used to evaluate the impact of $\mathrm{BI}$ interventions along with common outcomes analyzed by each study. Furthermore, we examined the commonalities in the data analysis methods across the included studies and made note of any external data sources that were triangulated with data collected during the BI interventions. In addition, any considerations around implementation of a BI intervention discussed by the authors were also noted and analyzed to identify the common themes. As this systematic review is focused on methodology rather than outcomes, when a large number of outcomes were reported in one resource (e.g., a book or final report about an experiment) the main outcome and health outcomes were prioritized.

The quality of 53 articles that included primary data analysis was assessed using the Joanna Briggs Institute (JBI) critical appraisal tools [35]. The JBI tools were selected because of the heterogeneity in the study designs captured in our review and JBI offers a comprehensive selection of pragmatic checklists that address different types of study. Twenty-three articles were assessed using the checklist for RCTs, and the same number of articles were assessed using the economic evaluation checklist. Four articles were simultaneously evaluated using checklists for RCTs and economic evaluations, given their adoption of both designs [36-39]. Checklist for case series was used to critically appraise 2 articles [40, 41], and another article was assessed using the checklist for quasi-experimental studies [42].

\section{Results}

Our search identified 6146 citations by database and 383 citations through grey literature searches, expert 
contacts and search of reference lists. After removing duplicate publications, 4668 citations remained for screening. Following abstract and title review, 805 fulltext citations were assessed for eligibility. The most common reason for exclusion was a failure to discuss methods to evaluate an unconditional BI experiment $(n=304)$. During full-text review, 27 additional duplicates were identified. Sixty-six articles could not be retrieved, the majority were published more than 30 years ago. Only two studies from the grey literature search met inclusion criteria. A total of 86 citations met the eligibility criteria for inclusion (Fig. 1). Of these, fifty-three articles conducted analysis of the primary data and were critically appraised (Additional File 2).

Of the 86 articles included, 63 were based on studies in the United States, 9 in Canada, and five were focused on studies in both the United States and Canada. The remaining articles were about the Madhya Pradesh Unconditional Cash Transfers Project (MPUCT) in India $(n=4)$, the BIG Pilot Project in Namibia $(n=3)$, and BI programs in Kenya $(n=1)$ and Finland $(n=1)$. Most of the American and Canadian studies $(n=77)$ were based on 5 experiments that involved BI programs that utilized a NIT model. NIT, or negative income tax, is a system that allows the state to pay benefits to people whose income falls below a certain threshold of tax liability, while people whose income exceeds the threshold pay tax to the state. As their income increases, the amount of benefits received by eligible individuals also decreases [43]. One US study assessed a citizen's dividend model that was implemented in Alaska. Under this system, all Alaskan residents are entitled to a yearly dividend payment from the Alaska Permanent Fund, which is funded by the state's oil revenues [42]. The Indian, Namibian, Kenyan, and Finland BI programs involved unconditional cash transfers (UCTs). Figure 2 presents the number of studies that emerged from each of the BI programs captured in this review.

\section{Details of $\mathrm{BI}$ studies}

Ten basic income experiments and programs were identified in this review, with four of them being carried out in the United States from the 1960s-70s: the New Jersey Income Maintenance Experiment (NJ), The Rural Income Maintenance Experiment (RIME), the Gary Income Maintenance Experiment (Gary), and the SeattleDenver Income Maintenance Experiment (SIME/DIME). These American income maintenance experiments were the first Randomized Controlled Trials (RCT) conducted in a community setting rather than a clinical setting.

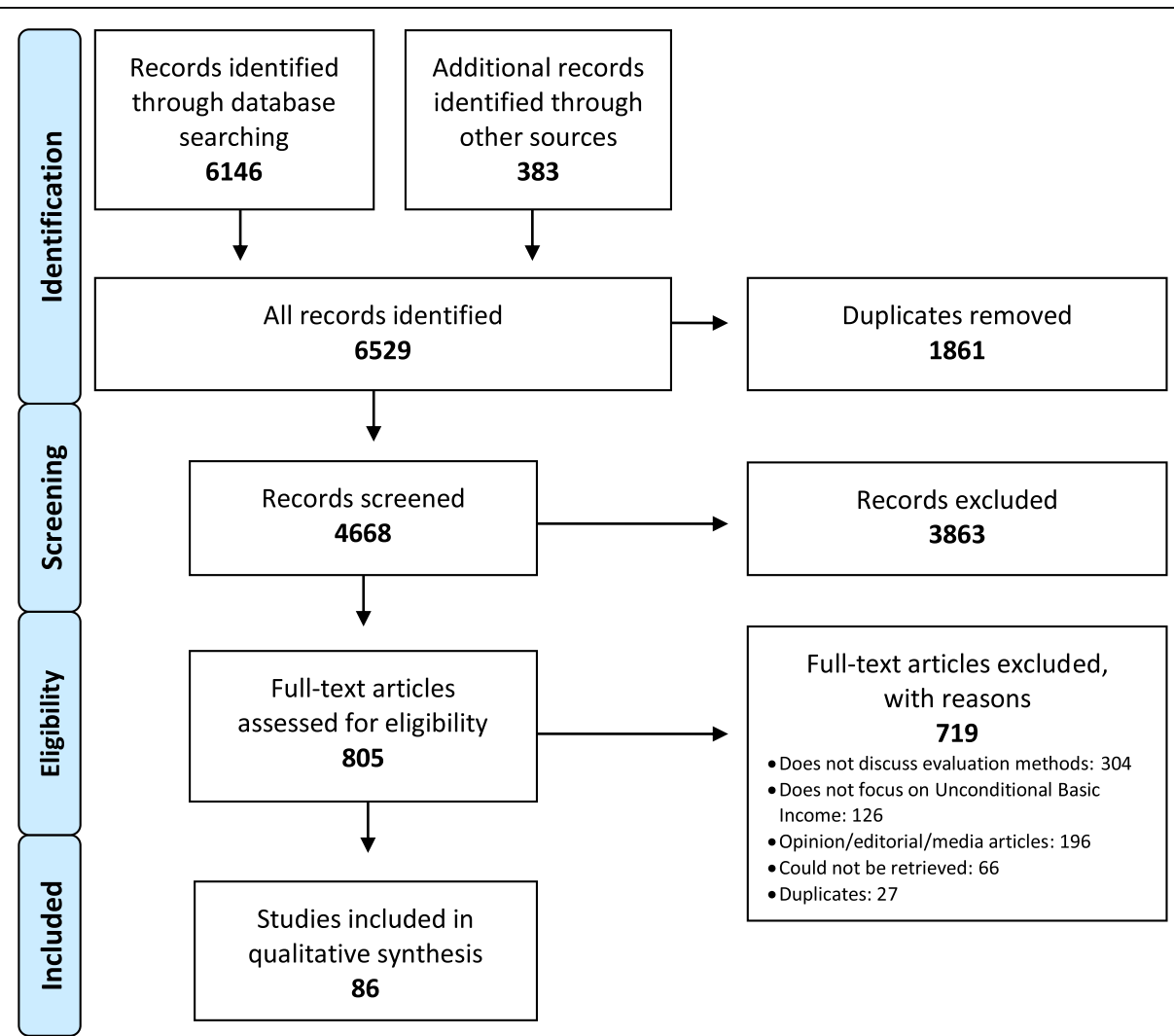

Fig. 1 Selection Process of Articles 


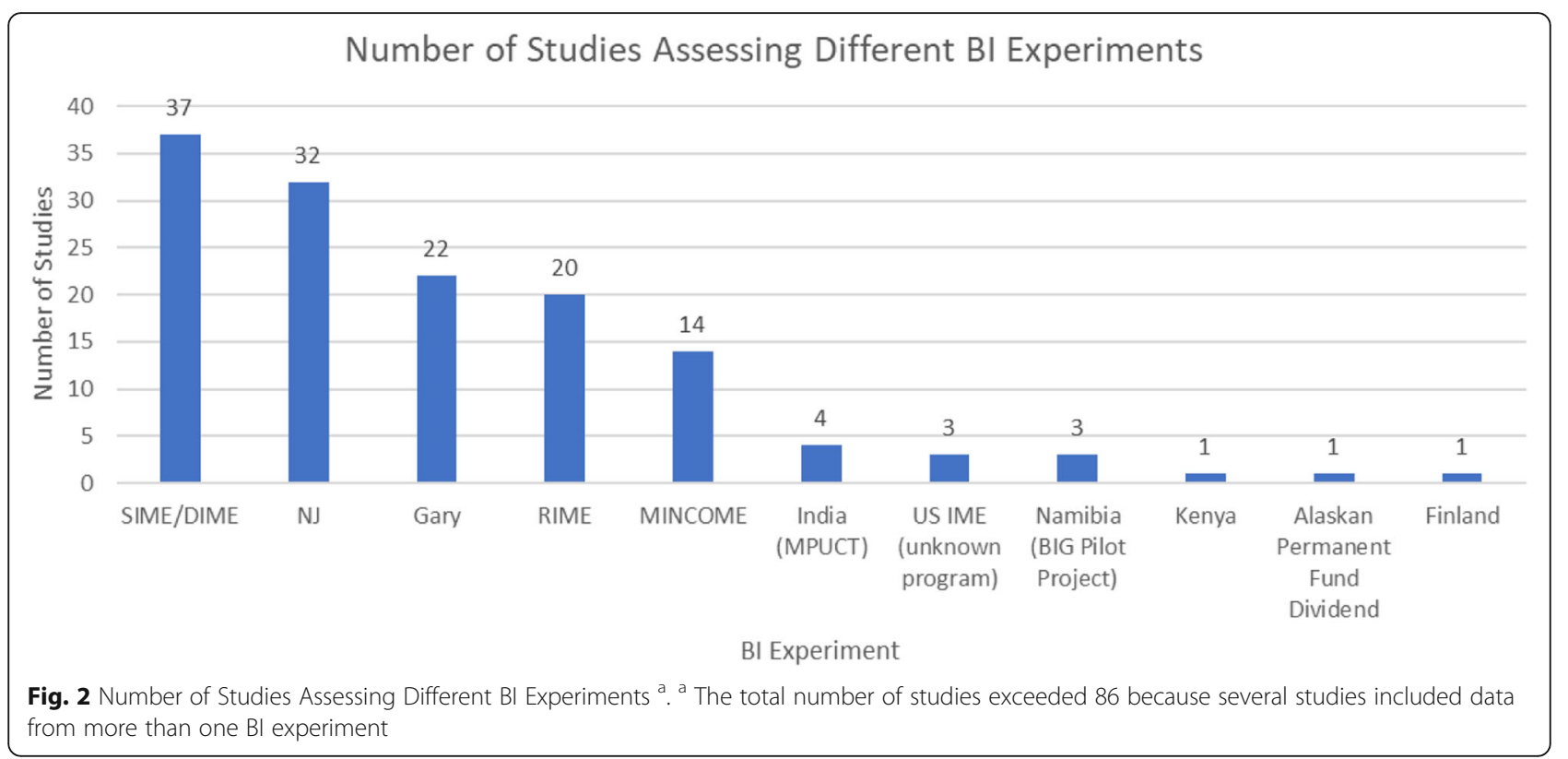

The main purpose for all of the experiments was to measure the labour supply response to BI guarantee (i.e. would BI result in a decline of work effort). In total, eight BI experiments included in this review were designed as RCTs, with only the BIG project in Namibia and the Alaska Permanent Dividend Fund in the US adopting observational design (Table 1). The sample sizes in the BI experiments that implemented an RCT design were relatively large, ranging from 809 participants in the RIME experiment to 11,688 participants in the MPUCT (Table 1). The BIG project in Namibia involved 398 individuals, while the study on the Alaska Permanent Dividend Fund observed data from about 48 million individuals (Table 1 ).

The NJ Experiment ran from 1968 to 1972 and was proposed to measure the labour supply response of urban males aged 18-58 [46]. To address the gap in knowledge with respect to BI impacts on labour supply in rural communities, RIME was initiated [47]. RIME took place in various locations across the United States, included single parent female headed households and was conducted from 1970 to 1972 [48]. Gary was an NIT experiment that was carried out from 1971 to 1974 and involved urban families who were mostly black and headed by females, which distinguished it from the other BI interventions in the US that involved a high proportion of white families $[49,50]$. Finally, the SIME/DIME study had a considerably larger sample size than the other American experiments and was the only experiment with a treatment duration longer than 3 years, spanning from 1970 to 1976 [51, 52]. The sample assignment for each study utilized the Conlisk-Watts Assignment Model, which was developed to scientifically optimize placement of participants within the treatment groups based on characteristics relevant to the outcomes being analyzed (Table 1) [44].

The Manitoba Income Maintenance Experiment (MINCOME) was also conducted from 1974 to 1979 in urban Winnipeg and rural Dauphin, Manitoba. This experiment was designed as an RCT and was the only one to include a saturation site (Dauphin, Manitoba), which presented an opportunity to look at the effects a BI would have on the community as a whole. The focus of this experiment was also on labour supply, similar to the American experiments. Unfortunately, the majority of the data collected during the study was never analyzed due to budgetary constraints (Table 1) [10].

Conducted from 2008 to 2010, the Namibian BIG Pilot Project was purported to be the first universal UCT program in the world and was designed as an observational cohort experiment [40]. A monthly BI grant was provided to approximately 1000 participants, of whom 398 were followed with surveys every 6 months. The main purposes of the pilot were to reduce poverty and improve social behaviours and the local economy. The intervention has been reported as having a large positive effect on the main outcomes as well as health outcomes $[40,41]$.

The Madhya Pradesh Unconditional Cash Transfer Project (MPUCT) was conducted in India from 2011 to 2012 and included 11,688 individuals [45]. This experiment adopted the RCT study design and a cluster 
Table 1 Basic Income Experiments and Programs

\begin{tabular}{|c|c|c|c|c|c|c|}
\hline $\begin{array}{l}\text { Basic Income } \\
\text { Experiment/ } \\
\text { Program }\end{array}$ & Location & Study Design & Years & Sample \# ${ }^{a}$ & $\begin{array}{l}\text { Sample } \\
\text { Description }\end{array}$ & $\begin{array}{l}\text { Survey } \\
\text { Timeline }\end{array}$ \\
\hline $\begin{array}{l}\text { New Jersey } \\
\text { Income } \\
\text { Maintenance } \\
\text { Experiment } \\
\text { (NJ) }\end{array}$ & $\begin{array}{l}\text { Trenton, Paterson, } \\
\text { Passaic, Jersey } \\
\text { City, New Jersey; } \\
\text { Scranton, } \\
\text { Pennsylvania, USA }\end{array}$ & $\begin{array}{l}\text { Randomized } \\
\text { Controlled } \\
\text { Trial }\end{array}$ & $\begin{array}{l}1968- \\
1972\end{array}$ & $\begin{array}{l}1357 \\
\text { households } \\
\text { (725 } \\
\text { intervention; } \\
632 \text { control } \\
[44])\end{array}$ & $\begin{array}{l}\text { Adult males 18- } \\
58 \text { and at least } \\
\text { one other family } \\
\text { member }\end{array}$ & $\begin{array}{l}\text { Pre-enrollment } \\
\text { Interview, } \\
\text { Baseline } \\
\text { Interview, } \\
\text { Twelve } \\
\text { Quarterly } \\
\text { Interviews, a } \\
\text { follow-up inter- } \\
\text { view } 3 \text { months } \\
\text { after the last } \\
\text { payment was } \\
\text { made. }\end{array}$ \\
\hline
\end{tabular}

$\begin{array}{lllll}\text { Rural Income } & \text { Duplin County, } & \text { Randomized } & 1970- & 809 \text { families } \\ \text { Maintenance } & \text { lowa; Calhoun } & \text { Controlled } & 1972 & (372 \\ \text { Experiment } & \text { and Pocahontas } & \text { Trial } & & \text { intervention; } \\ \text { (RIME) } & \text { Counties, North } & & 437 \text { control } \\ & \text { Carolina, USA } & & [44])\end{array}$

Gary Income Maintenance Experiment (Gary)

\section{Gary, Indiana, USA Randomized Controlled Trial}

\begin{tabular}{|c|c|c|}
\hline $\begin{array}{l}\text { Seattle/Denver } \\
\text { Income } \\
\text { Maintenance } \\
\text { Experiment } \\
\text { (SIME/DIME) }\end{array}$ & $\begin{array}{l}\text { Seattle, } \\
\text { Washington; } \\
\text { Denver, Colorado, } \\
\text { USA }\end{array}$ & $\begin{array}{l}\text { Randomized } \\
\text { Controlled } \\
\text { Trial }\end{array}$ \\
\hline $\begin{array}{l}\text { Manitoba } \\
\text { Guaranteed } \\
\text { Annual } \\
\text { Income } \\
\text { Experiment } \\
\text { (MINCOME) }\end{array}$ & $\begin{array}{l}\text { Winnipeg, } \\
\text { Manitoba, } \\
\text { CanadaSaturation } \\
\text { Site: Rural } \\
\text { community of } \\
\text { Dauphin and a } \\
\text { number of small } \\
\text { rural } \\
\text { communities. }\end{array}$ & $\begin{array}{l}\text { Randomized } \\
\text { Controlled } \\
\text { Trial }\end{array}$ \\
\hline
\end{tabular}

1979 families (575 intervention; 612 control [44]
$1974->1300$
Adults 18-58 including either two-parent or single parent households headed by females with at least one other family member; rural areas
1971- 1799 families $1974 \quad(1028$ intervention; 771 control [44])

Black adults 1858 including single parent families especially headed by females and at least one other family member

1970- 4800 families $1976 \quad$ (2747 intervention; 2053 control [44])
Adults 18-58 with at least one other family member
Adults 18-58 with at least one other family member; Institutionalized, retired, or disabled were excluded from Winnipeg. Elderly and disabled not excluded from Dauphin
Baseline Interview, 12 quarterly Interviews, follow-up interview 3 months after the last payment
Baseline interview and eight interviews about every 4 months

Baseline interview and interviews about every 4 months

\section{Income Data Other Data}

Collection Sources

Income Data - Schools,

Forms;Pay hospitals,

stubs;Social public

Security organizations

aggregate

data

Periodic Audit

offering

services to the

Forms

poor, and

other relevant

institutions and

organizations

- Family

composition

reporting:

monthly for

experimental

and every 4

months for

controls

Periodic Audit - Schools,

Forms hospitals,

public

organizations

offering

services to the

poor, and

other relevant

institutions and

organizations

- Family

composition

reporting:

monthly for

experimental

and every 4

months for

controls

Monthly - Family

Income Report composition

FormsPeriodic reporting:

Audit Forms monthly for

experimental

and every 4

months for

controls

Monthly - Family

Income Report composition

Forms Periodic reporting:

monthly for

experimental

and every 4

months for

controls

Baseline

interview and

interviews 3

times per year

None listed

- The Manitoba

Population

Health

Research Data

Repository

database

- Use of

aggregate data

from the

Department of

Education 
Table 1 Basic Income Experiments and Programs (Continued)

\begin{tabular}{|c|c|c|c|c|c|c|c|c|}
\hline $\begin{array}{l}\text { Basic Income } \\
\text { Experiment/ } \\
\text { Program }\end{array}$ & Location & Study Design & Years & Sample $\#^{a}$ & $\begin{array}{l}\text { Sample } \\
\text { Description }\end{array}$ & $\begin{array}{l}\text { Survey } \\
\text { Timeline }\end{array}$ & $\begin{array}{l}\text { Income Data } \\
\text { Collection }\end{array}$ & $\begin{array}{l}\text { Other Data } \\
\text { Sources }\end{array}$ \\
\hline & & & & & (saturation site). & & & \\
\hline $\begin{array}{l}\text { Alaska } \\
\text { Permanent } \\
\text { Dividend } \\
\text { Fund }\end{array}$ & Alaska, USA & $\begin{array}{l}\text { Observational: } \\
\text { Differences in } \\
\text { Difference }\end{array}$ & $\begin{array}{l}1977- \\
2015\end{array}$ & 48,686, 169 & $\begin{array}{l}\text { All residents of } \\
\text { Alaska and all } \\
\text { residents of } \\
\text { control states } \\
\text { that have been } \\
\text { matched with } \\
\text { Alaska on } \\
\text { employment to } \\
\text { population ratio } \\
\text { and the } \\
\text { population share } \\
\text { working part-time }\end{array}$ & $\begin{array}{l}\text { Monthly surveys, } \\
\text { with some } \\
\text { questions asked } \\
\text { at fourth and } \\
\text { eighth month of } \\
\text { the survey } \\
\text { (Integrated } \\
\text { Public Use } \\
\text { Microdata } \\
\text { Series - Current } \\
\text { Population } \\
\text { Surveys (CPS) } \\
\text { provided by the } \\
\text { Minnesota } \\
\text { Population } \\
\text { Center) }\end{array}$ & None listed & $\begin{array}{l}\text { - CPS Merged } \\
\text { Outgoing } \\
\text { Rotation } \\
\text { Groups (MORG) } \\
\text { provided by } \\
\text { the National } \\
\text { Bureau of } \\
\text { Economic } \\
\text { Research } \\
\text { (NBER) for } \\
\text { number of } \\
\text { hours worked }\end{array}$ \\
\hline $\begin{array}{l}\text { Namibia Basic } \\
\text { Income Grant } \\
\text { Pilot Project }\end{array}$ & $\begin{array}{l}\text { Otjivero-Omitara, } \\
\text { Namibia }\end{array}$ & $\begin{array}{l}\text { Observational: } \\
\text { cohort }\end{array}$ & $\begin{array}{l}2008- \\
2010\end{array}$ & $\begin{array}{l}398 \text { individuals } \\
\text { [40] }\end{array}$ & $\begin{array}{l}\text { All individuals } \\
\text { under } 60 \text { years }\end{array}$ & $\begin{array}{l}\text { Baseline, 6- } \\
\text { month, 11- } \\
\text { month surveys }\end{array}$ & None listed & $\begin{array}{l}\text { - Key informant } \\
\text { interviews: e.g., } \\
\text { local nurse, } \\
\text { police chief, } \\
\text { local leaders } \\
\text { and shop } \\
\text { keepers } \\
\text { - Case studies } \\
\text { including } \\
\text { pictures }\end{array}$ \\
\hline $\begin{array}{l}\text { Madhya } \\
\text { Pradesh } \\
\text { Unconditional } \\
\text { Cash Transfer } \\
\text { (MPUCT) }\end{array}$ & $\begin{array}{l}\text { Rural Villages, } \\
\text { Indore District; } \\
\text { Rural Tribal } \\
\text { Villages, Indore } \\
\text { District, Madhya } \\
\text { Pradesh, India }\end{array}$ & $\begin{array}{l}\text { Modified } \\
\text { Randomized } \\
\text { Controlled } \\
\text { Trial }\end{array}$ & $\begin{array}{l}2011- \\
2012\end{array}$ & $\begin{array}{l}11,688 \\
\text { individuals; } \\
2034 \\
\text { households (8 } \\
\text { villages } \\
\text { randomly } \\
\text { assigned to } \\
\text { intervention; } \\
12 \text { villages to } \\
\text { control [45]) }\end{array}$ & $\begin{array}{l}\text { Universal: all } \\
\text { individuals within } \\
\text { the villages }\end{array}$ & $\begin{array}{l}\text { Baseline survey, } \\
\text { interim } \\
\text { evaluation } \\
\text { survey, final } \\
\text { evaluation } \\
\text { survey, post-final } \\
\text { evaluation } \\
\text { Survey }\end{array}$ & None listed & $\begin{array}{l}\text { - Case Studies } \\
\text { including } \\
\text { structured } \\
\text { interviews } \\
\text { - Community } \\
\text { level surveys } \\
\text { - Interviews with } \\
\text { key } \\
\text { respondents } \\
\text { - Tracking of } \\
\text { children's } \\
\text { weight for age } \\
\text { - Tracking of } \\
\text { children's } \\
\text { attendance } \\
\text { and school } \\
\text { performance }\end{array}$ \\
\hline $\begin{array}{l}\text { Give Directly } \\
\text { Unconditional } \\
\text { Cash Transfer } \\
\text { Program }\end{array}$ & $\begin{array}{l}\text { Rural Rarieda } \\
\text { Region, Kenya }\end{array}$ & $\begin{array}{l}\text { Two-level } \\
\text { cluster- } \\
\text { Randomized } \\
\text { Controlled } \\
\text { Trial }\end{array}$ & $\begin{array}{l}2011- \\
2013\end{array}$ & $\begin{array}{l}1440 \\
\text { households } \\
\text { (503 } \\
\text { intervention; } \\
432 \text { "pure" } \\
\text { control in } \\
\text { control } \\
\text { villages; } 505 \\
\text { "spillover" } \\
\text { control in } \\
\text { intervention } \\
\text { villages [36]) }\end{array}$ & $\begin{array}{l}\text { Individuals living } \\
\text { in a house with a } \\
\text { thatch roof }\end{array}$ & $\begin{array}{l}\text { Baseline and } \\
\text { endline surveys }\end{array}$ & None listed & $\begin{array}{l}\text { - Saliva samples } \\
\text { to measure } \\
\text { cortisol levels } \\
\text { - Height, weight, } \\
\text { and upper-arm } \\
\text { circumference } \\
\text { of children } \\
\text { under five } \\
\text { years } \\
\text { - Interviews with } \\
\text { village dwellers }\end{array}$ \\
\hline
\end{tabular}


Table 1 Basic Income Experiments and Programs (Continued)

\begin{tabular}{|c|c|c|c|c|c|c|c|c|}
\hline $\begin{array}{l}\text { Basic Income } \\
\text { Experiment/ } \\
\text { Program }\end{array}$ & Location & Study Design & Years & Sample \# & $\begin{array}{l}\text { Sample } \\
\text { Description }\end{array}$ & $\begin{array}{l}\text { Survey } \\
\text { Timeline }\end{array}$ & $\begin{array}{l}\text { Income Data } \\
\text { Collection }\end{array}$ & $\begin{array}{l}\text { Other Data } \\
\text { Sources }\end{array}$ \\
\hline $\begin{array}{l}\text { Finland Basic } \\
\text { Income } \\
\text { Experiment }\end{array}$ & $\begin{array}{l}\text { Mixed Rural and } \\
\text { Urban Areas in } \\
\text { Finland }\end{array}$ & $\begin{array}{l}\text { Randomized } \\
\text { Control Trial }\end{array}$ & $\begin{array}{l}2017- \\
2018\end{array}$ & $\begin{array}{l}175,000 \text { (for } \\
\text { the registry } \\
\text { data) and } \\
1633 \text { (for } \\
\text { survey) }\end{array}$ & $\begin{array}{l}\text { Individuals aged } \\
25-58 \text { receiving } \\
\text { unemployment } \\
\text { benefits from } \\
\text { Kela (Finnish } \\
\text { social insurance } \\
\text { institution) }\end{array}$ & $\begin{array}{l}\text { Baseline survey } \\
\text { and one interim } \\
\text { survey nearing } \\
\text { the end of the } \\
\text { intervention }\end{array}$ & None listed & $\begin{array}{l}\text { - Administrative } \\
\text { data on } \\
\text { employment } \\
\text { - Qualitative } \\
\text { interviews } \\
\text { (results not } \\
\text { reported in the } \\
\text { preliminary } \\
\text { report) }\end{array}$ \\
\hline
\end{tabular}

${ }^{a}$ Sample size is often not consistently reported. The sample size is referenced throughout

sampling method. In this experiment, villages, rather than individuals, were randomly selected for the intervention or control sites. All participants living within a selected experimental village received the BI payments for 1 year. The main purpose of the experiment was to lift people out of poverty (Table 1) [53].

An UCT program was also conducted in Kenya from 2011 to 2013 with 1440 individuals. This project used an RCT design and involved multiple treatment arms ranging from a one-time transfer payment to nine monthly installments. Household recipients were also randomized (in addition to households being randomly selected to participate). The main purpose of the experiment included measuring work effort response, behavioural effects and psychological well-being (Table 1) [36].

In January 2017, Finland introduced a partial BI experiment that followed two thousand recipients aged 25-58 years for 2 years. Following the RCT principle, participants were sampled randomly from the Finnish population who received regular unemployment benefit without any regional or other emphasis. Similar to the other BI experiments, their main purpose was to investigate whether a BI could provide stronger incentive for workforce participation than the current social security system. The preliminary findings of the experiment were published in 2019 and utilized both administrative and survey data (Table 1) [54].

Lastly, an observational study completed in the US examined the impact of a permanent fund dividend provided to Alaskan residents on the state's labour market. This cash transfer was introduced in 1977 and has continued until the present. The study included in this review used population survey and census data from 1977 to 2015 . The impact of the fund was measured by evaluating the change in employment and part-time jobs, change in labour force participation, and change in worked hours (Table 1) [42].

\section{Methods used in BI studies}

The articles included in the review evaluated the impacts of BI intervention on seven major domains. About half of the papers $(n=40)$ focused on outcomes relating to labour supply or workforce participation. The second most common domain to be evaluated was health outcomes ( $n=11)$, including fertility, hospitalization rates, nutrition, and birth weights, followed by income level and living conditions $(n=10)$. Family stability, particularly marital dissolution, also became the focus of nine articles based on the four major BI experiments in the US, namely NJ, RIME, Gary, and SIME/DIME. Several articles $(n=7)$ also examined elements that can affect the implementation and analysis of a BI experiment, henceforth described as the methods domain, such as potential underreporting of employment status and income level, stigma that may hinder participation in a BI experiment and other social welfare, and the potential understatement of the effects of BI intervention due to the temporary nature of the experiment [55-57]. The two other major domains that were assessed include education-related outcomes $(n=6)$ and asset ownership [3]. A few other articles also examined the impact of BI intervention on awareness of social services, risk-taking in labour market and rate of migration [58-61]. Details of the main outcomes evaluated in each article are described in Table 2.

Throughout the past six decades, workforce participation consistently became the most evaluated domains of $\mathrm{BI}$ intervention, with up to 17 articles drawing information from labour data taken during the BI experiments in the 1970's (Fig. 3). Some study interest on health-related outcomes was also shown during the 1970's, before declining in the next three decades and picking up again in 2010's. Family stability was also consistently evaluated between the 1970's and the 1990's, but research interest in this domain seemed to decrease in the 2000's. Conversely, the impacts of BI on income level and living conditions only began to gain interest in the last two decades.

The data collection process for each of the experimental studies involved either interviews at baseline and periodic points in time throughout the intervention period or the use of surveys. The NJ had the greatest quantity of surveys, including a pre-enrollment, baseline, twelve quarterly interviews and a follow-up interview. The other US-based experiments followed a similar structure, most including a baseline interview, 8-12 quarterly interviews and follow-up 
Table 2 Data Extraction Outcomes

\begin{tabular}{|c|c|c|c|c|c|c|}
\hline No & $\begin{array}{l}\text { Authors, } \\
\text { Year }\end{array}$ & $\begin{array}{l}\text { Basic } \\
\text { Income } \\
\text { Experiment }\end{array}$ & $\begin{array}{l}\text { Type of Basic } \\
\text { Income }\end{array}$ & Country & Main Outcome & Main Outcome Results \\
\hline 1 & $\begin{array}{l}\text { Ashenfelter, } \\
1990 \text { [74] }\end{array}$ & SIME/DIME & NIT & USA & Labour supply & $\begin{array}{l}\text { Incentive effects on labour supply would have a } \\
\text { real effect on the transfer costs of such a } \\
\text { program }\end{array}$ \\
\hline 2 & $\begin{array}{l}\text { Baumol, } \\
1974 \text { [73] }\end{array}$ & $\begin{array}{l}\text { US IMES } \\
\text { (not } \\
\text { specified) }\end{array}$ & NIT & USA & Housing consumption behaviour & Increase in home ownership \\
\hline 3 & $\begin{array}{l}\text { Bawden, } \\
1970[48]\end{array}$ & NJ, RIME & NIT & USA & Work incentive & None \\
\hline 4 & $\begin{array}{l}\text { Beck et al., } \\
2015[45]\end{array}$ & India & $\mathrm{UCT}$ & India & $\begin{array}{l}\text { Illness or injury in the household and } \\
\text { vaccination coverage }\end{array}$ & $\begin{array}{l}\text { Less minor illness or injury in the household } \\
\text { found in the intervention group, but no effect } \\
\text { on vaccination coverage and serious illness and } \\
\text { injuries }\end{array}$ \\
\hline 5 & $\begin{array}{l}\text { SEWA Bharat, } \\
2014[53]\end{array}$ & India & $U C T$ & India & $\begin{array}{l}\text { Basic living conditions including } \\
\text { sanitation, drinking water, energy } \\
\text { sources }\end{array}$ & $\begin{array}{l}\text { Basic living improved including sanitation, } \\
\text { energy sources }\end{array}$ \\
\hline 6 & $\begin{array}{l}\text { Bishop, } 1980 \\
\text { [69] }\end{array}$ & $\begin{array}{l}\text { NJ, RIME, } \\
\text { Gary, SIME/ } \\
\text { DIME }\end{array}$ & NIT & USA & Marital dissolution rates & Rates of marital dissolution were higher \\
\hline 7 & $\begin{array}{l}\text { Brodkin and } \\
\text { Kaufman, } \\
2000[87]\end{array}$ & $\begin{array}{l}\text { NJ, SIME/ } \\
\text { DIME }\end{array}$ & NIT & USA & Labour supply & $\begin{array}{l}\text { Labour supply showed very little evidence of a } \\
\text { work disincentive }\end{array}$ \\
\hline 8 & $\begin{array}{l}\text { Burtless, } \\
1986[88]\end{array}$ & $\begin{array}{l}\text { NJ, RIME, } \\
\text { Gary, SIME/ } \\
\text { DIME }\end{array}$ & NIT & USA & Work hours and earnings & $\begin{array}{l}\text { Work hours and earnings are decreased among } \\
\text { NIT recipients across all four experiments }\end{array}$ \\
\hline 9 & $\begin{array}{l}\text { Burtless and } \\
\text { Greenberg, } \\
1981[68]\end{array}$ & SIME/DIME & NIT & USA & Work hours & $\begin{array}{l}\text { The estimated reduction in hours is larger when } \\
\text { the analysis focuses on those below the } \\
\text { breakeven level }\end{array}$ \\
\hline 10 & $\begin{array}{l}\text { Burtless and } \\
\text { Greenberg, } \\
1982[89]\end{array}$ & SIME/DIME & NIT & USA & Labour supply & $\begin{array}{l}\text { Reduction in labor supply was larger in the } 5 \text { - } \\
\text { year experimental sample than the 3-year one }\end{array}$ \\
\hline 11 & $\begin{array}{l}\text { Burtless and } \\
\text { Hausman, } \\
1978[90]\end{array}$ & Gary & NIT & USA & Labour supply & $\begin{array}{l}\text { Labour supply is largely unaffected by NIT, but } \\
\text { it may be reduced by poor health and aging }\end{array}$ \\
\hline 12 & $\begin{array}{l}\text { Byrne, } 1973 \\
{[91]}\end{array}$ & NJ, Gary & NIT & USA & $\begin{array}{l}\text { Mother's work disincentives with day- } \\
\text { care costs }\end{array}$ & $\begin{array}{l}\text { Mothers have a disincentive to work when } \\
\text { faced with day-care costs }\end{array}$ \\
\hline 13 & $\begin{array}{l}\text { Cain and } \\
\text { Wissoker, } \\
1990[72]\end{array}$ & SIME/DIME & NIT & USA & $\begin{array}{l}\text { Marital Stability when accounting for } \\
\text { potential bias from different durations } \\
\text { of experiments }\end{array}$ & $\begin{array}{l}\text { Impact of NIT on marital breakups decline with } \\
\text { the length of the programs }\end{array}$ \\
\hline 14 & $\begin{array}{l}\text { Cain et al., } \\
1974[92]\end{array}$ & NJ & NIT & USA & Labour supply of married women & $\begin{array}{l}\text { Disincentives with labor-force participation for } \\
\text { white wives }\end{array}$ \\
\hline 15 & $\begin{array}{l}\text { Calnitsky, } \\
2016[55]\end{array}$ & MINCOME & NIT & Canada & Community experience & $\begin{array}{l}\text { - Motives to participate in MINCOME are related } \\
\text { to money/assistance } \\
\text { - Social stigma experienced by MINCOME } \\
\text { recipients was lower than welfare recipients }\end{array}$ \\
\hline 16 & $\begin{array}{l}\text { Choudhry } \\
\text { and Arvin, } \\
2001 \text { [93] }\end{array}$ & MINCOME & NIT & Canada & $\begin{array}{l}\text { Family income level and marital } \\
\text { dissolution }\end{array}$ & $\begin{array}{l}\text { Increase in marital dissolution with lower family } \\
\text { income level }\end{array}$ \\
\hline 17 & $\begin{array}{l}\text { Choudhry } \\
\text { and Hum, } \\
1995 \text { [94] }\end{array}$ & MINCOME & NIT & Canada & Income level and marital dissolution & $\begin{array}{l}\text { NIT payments did not encourage splits by } \\
\text { lowering the financial costs of marital disruption }\end{array}$ \\
\hline 18 & $\begin{array}{l}\text { Connor, } \\
\text { Rodgers, and } \\
\text { Priest, } 1999 \\
{[44]}\end{array}$ & $\begin{array}{l}\text { NJ, RIME, } \\
\text { Gary, SIME/ } \\
\text { DIME, } \\
\text { MINCOME }\end{array}$ & NIT & $\begin{array}{l}\text { USA } \\
\text { and } \\
\text { Canada }\end{array}$ & Marital stability, nutrition, education & $\begin{array}{l}\text { No consistent effects on marital stability, } \\
\text { nutrition or education }\end{array}$ \\
\hline 19 & $\begin{array}{l}\text { Curry, } 1981 \\
{[95]}\end{array}$ & NJ & NIT & USA & Work effort & Work effort did not decline \\
\hline
\end{tabular}


Table 2 Data Extraction Outcomes (Continued)

\begin{tabular}{|c|c|c|c|c|c|c|}
\hline No & $\begin{array}{l}\text { Authors, } \\
\text { Year }\end{array}$ & $\begin{array}{l}\text { Basic } \\
\text { Income } \\
\text { Experiment }\end{array}$ & $\begin{array}{l}\text { Type of Basic } \\
\text { Income }\end{array}$ & Country & Main Outcome & Main Outcome Results \\
\hline 20 & $\begin{array}{l}\text { Davala et al., } \\
2015[76]\end{array}$ & India & UCT & India & Debt and Borrowing & Debt and borrowing reduced \\
\hline 21 & $\begin{array}{l}\text { Dickinson } \\
\text { and Watts, } \\
1975[85]\end{array}$ & NJ, RIME & NIT & USA & $\begin{array}{l}\text { Uses of the Data: labor supply } \\
\text { response }\end{array}$ & $\begin{array}{l}\text { Labor supply response was focus of } \\
\text { experimental design }\end{array}$ \\
\hline 22 & $\begin{array}{l}\text { Elesh and } \\
\text { Lefcowitz, } \\
1977 \text { [96] }\end{array}$ & NJ & NIT & USA & Health and health care utilization & $\begin{array}{l}\text { No effect observed on health and health care } \\
\text { utilization. }\end{array}$ \\
\hline 23 & $\begin{array}{l}\text { Forget, } 2011 \\
{[10]}\end{array}$ & MINCOME & NIT & Canada & Hospitalization rates & Hospitalization rates fell \\
\hline 24 & $\begin{array}{l}\text { Forget, } 2013 \\
{[64]}\end{array}$ & MINCOME & NIT & Canada & Hospital separations & Hospital separations declined \\
\hline 25 & $\begin{array}{l}\text { Forget, } 2010 \\
{[97]}\end{array}$ & $\begin{array}{l}\text { NJ, RIME, } \\
\text { Gary, SIME/ } \\
\text { DIME, } \\
\text { MINCOME }\end{array}$ & NIT & $\begin{array}{l}\text { USA } \\
\text { and } \\
\text { Canada }\end{array}$ & Work effort & US: reduction in work effort \\
\hline 26 & $\begin{array}{l}\text { Forget et al., } \\
2013[98]\end{array}$ & MINCOME & NIT & Canada & Hospitalization rates & Hospitalization rates fell \\
\hline 27 & $\begin{array}{l}\text { Greenberg } \\
\text { and Halsey, } \\
1983[56]\end{array}$ & SIME/DIME & NIT & USA & $\begin{array}{l}\text { Underreporting of employment and } \\
\text { quarterly earnings }\end{array}$ & $\begin{array}{l}\text { Higher degree of underreporting of } \\
\text { employment status and earning by intervention } \\
\text { recipients compared to that by the control } \\
\text { group }\end{array}$ \\
\hline 28 & $\begin{array}{l}\text { Greenberg, } \\
\text { Moffitt, } \\
\text { Friedmann, } \\
1981[65]\end{array}$ & Gary & NIT & USA & Underreporting and work effort & Underreporting work effort was substantial \\
\hline 29 & $\begin{array}{l}\text { Groeneveld } \\
\text { et al., } 1980 \\
\text { [70] }\end{array}$ & SIME/DIME & NIT & USA & Marital dissolution & $\begin{array}{l}\text { SIME/DIME increased the rate of marital } \\
\text { dissolution }\end{array}$ \\
\hline 30 & $\begin{array}{l}\text { Haarmann, } \\
2008[40]\end{array}$ & $\begin{array}{l}\text { BIG Pilot } \\
\text { Project } \\
\text { (Namibia) }\end{array}$ & UCT & Namibia & Nutrition and child development & Reduced food shortages \\
\hline 31 & $\begin{array}{l}\text { Haarmann } \\
\text { et al., } 2009 \\
\text { [41] }\end{array}$ & Namibia & UCT & Namibia & Poverty Rates & Poverty rates decrease \\
\hline 32 & $\begin{array}{l}\text { Haushofer } \\
\text { and Shapiro, } \\
2013 \text { [36] }\end{array}$ & Kenya & UCT & Kenya & AssetsConsumption & Increased Asset Values \\
\hline 33 & $\begin{array}{l}\text { Heffernan, } \\
1977[60]\end{array}$ & RIME & NIT & USA & Awareness of social services & No effect on awareness of social services \\
\hline 34 & $\begin{array}{l}\text { Hollister, } \\
1974 \text { [99] }\end{array}$ & NJ & NIT & USA & $\begin{array}{l}\text { Total family hours and total family } \\
\text { earnings }\end{array}$ & $\begin{array}{l}\text { Significant response to the experimental } \\
\text { treatment by Whites and Spanish-speakers for } \\
\text { total family hours and total family earnings. }\end{array}$ \\
\hline 35 & $\begin{array}{l}\text { Hum and } \\
\text { Choudry, } \\
1992[100]\end{array}$ & MINCOME & NIT & Canada & $\begin{array}{l}\text { Family income level and marital } \\
\text { dissolution }\end{array}$ & $\begin{array}{l}\text { Social roles expected of each partner, not family } \\
\text { income, determines family stability }\end{array}$ \\
\hline 36 & $\begin{array}{l}\text { Hum and } \\
\text { Simpson, } \\
1991[101]\end{array}$ & MINCOME & NIT & Canada & $\begin{array}{l}\text { Labour Supply Response of Families } \\
\text { and Individuals }\end{array}$ & $\begin{array}{l}\text { Negative effect on work hours for single female } \\
\text { heads }\end{array}$ \\
\hline 37 & $\begin{array}{l}\text { Hum and } \\
\text { Simpson, } \\
1993[102]\end{array}$ & $\begin{array}{l}\text { NJ, RIME, } \\
\text { Gary, SIME/ } \\
\text { DIME, } \\
\text { MINCOME }\end{array}$ & NIT & $\begin{array}{l}\text { USA } \\
\text { and } \\
\text { Canada }\end{array}$ & Labor supply response & Insignificant changes in work behaviour \\
\hline 38 & $\begin{array}{l}\text { Huston, } 1999 \\
\text { [103] }\end{array}$ & $\begin{array}{l}\text { NJ, RIME, } \\
\text { Gary, SIME/ } \\
\text { DIME }\end{array}$ & NIT & USA & Children's educational outcomes & $\begin{array}{l}\text { Mixed effects on children's school performance } \\
\text { and attendance, achievement and aspirations, } \\
\text { high school completion, educational }\end{array}$ \\
\hline
\end{tabular}


Table 2 Data Extraction Outcomes (Continued)

\begin{tabular}{|c|c|c|c|c|c|c|}
\hline No & $\begin{array}{l}\text { Authors, } \\
\text { Year }\end{array}$ & $\begin{array}{l}\text { Basic } \\
\text { Income } \\
\text { Experiment }\end{array}$ & $\begin{array}{l}\text { Type of Basic } \\
\text { Income }\end{array}$ & Country & Main Outcome & Main Outcome Results \\
\hline & & & & & & attainment, employment. \\
\hline 39 & $\begin{array}{l}\text { Johnson, } \\
1980[61]\end{array}$ & $\begin{array}{l}\text { US IMES } \\
\text { (not } \\
\text { specified) }\end{array}$ & NIT & USA & Risk taking in labour market & Risk-taking rises with income \\
\hline 40 & $\begin{array}{l}\text { Jones and } \\
\text { Marinescu, } \\
2018[42]\end{array}$ & $\begin{array}{l}\text { Alaskan } \\
\text { Permanent } \\
\text { Fund } \\
\text { Dividend }\end{array}$ & $\mathrm{UCl}$ & USA & Evolution in labour market & $\begin{array}{l}\text { No change in employment within Alaska pre- } \\
\text { and post-dividend payment, and no difference } \\
\text { in labour market evolution between Alaska and } \\
\text { other states }\end{array}$ \\
\hline 41 & $\begin{array}{l}\text { Kaluzny, } \\
1979[49]\end{array}$ & NJ, Gary & NIT & USA & Home ownership & Increases in homeownership \\
\hline 42 & $\begin{array}{l}\text { Kangas et al., } \\
2019[104]\end{array}$ & Finland & $\mathrm{UCl}$ & Finland & Work effort & $\begin{array}{l}\text { No difference in average days in open } \\
\text { employment, but slight increase in self- } \\
\text { employment rate and their associated earnings }\end{array}$ \\
\hline 43 & $\begin{array}{l}\text { Keeley et al., } \\
1978[105]\end{array}$ & SIME/DIME & NIT & USA & Labour supply & $\begin{array}{l}\text { Income effects are negative for wives and } \\
\text { female heads; Substitution effects are positive }\end{array}$ \\
\hline 44 & $\begin{array}{l}\text { Keeley et al., } \\
1978 \text { [106] }\end{array}$ & SIME/DIME & NIT & USA & $\begin{array}{l}\text { Labour supply effects and costs of } \\
\text { alternative negative income tax } \\
\text { programs }\end{array}$ & $\begin{array}{l}\text { Labor-supply response and program costs vary } \\
\text { widely with the support level and tax rate }\end{array}$ \\
\hline 45 & $\begin{array}{l}\text { Keeley and } \\
\text { Robins, } 1979 \\
{[107]}\end{array}$ & SIME/DIME & NIT & USA & Work disincentives & SIME/DIME reduced hours of work \\
\hline 46 & $\begin{array}{l}\text { Keeley, } 1980 \\
{[58]}\end{array}$ & SIME/DIME & NIT & USA & Migration & $\begin{array}{l}\text { Increased rate of mobility for white married } \\
\text { males and females }\end{array}$ \\
\hline 47 & $\begin{array}{l}\text { Keeley, } 1980 \\
{[108]}\end{array}$ & SIME/DIME & NIT & USA & Fertility & $\begin{array}{l}\text { NIT negatively effects married whites' and } \\
\text { positively effects married Chicanos' fertility }\end{array}$ \\
\hline 48 & $\begin{array}{l}\text { Keeley, } 1980 \\
{[59]}\end{array}$ & SIME/DIME & NIT & USA & Rate of migration & Increased rate of migration \\
\hline 49 & $\begin{array}{l}\text { Keeley, } 1987 \\
{[109]}\end{array}$ & SIME/DIME & NIT & USA & Marital Dissolution & $\begin{array}{l}\text { Positive effect on marital dissolution/divorce } \\
\text { rates }\end{array}$ \\
\hline 50 & $\begin{array}{l}\text { Kehrer and } \\
\text { Wolin, } 1979 \\
\text { [63] }\end{array}$ & Gary & $\begin{array}{l}\text { NITTwo } \\
\text { guarantee } \\
\text { levels and two } \\
\text { tax rates }\end{array}$ & USA & Birth weight & No difference in birth weight \\
\hline 51 & $\begin{array}{l}\text { Kerachsky, } \\
1977[110]\end{array}$ & RIME & NIT & USA & Farm family labor supply & $\begin{array}{l}\text { Changes in guarantee produce a pattern of } \\
\text { negative effects on labor supply }\end{array}$ \\
\hline 52 & $\begin{array}{l}\text { Kershaw, } \\
1972[111]\end{array}$ & NJ & NIT & USA & Earnings & $\begin{array}{l}\text { No evidence indicating a significant decline in } \\
\text { weekly earnings }\end{array}$ \\
\hline 53 & $\begin{array}{l}\text { Kershaw and } \\
\text { Fair, } 1976 \\
{[84]}\end{array}$ & NJ & NIT & USA & Withdrawal from Work & No substantial withdrawal from work \\
\hline 54 & $\begin{array}{l}\text { Levine et al., } \\
2005[112]\end{array}$ & $\begin{array}{l}\text { NJ, RIME, } \\
\text { Gary, SIME/ } \\
\text { DIME }\end{array}$ & NIT & USA & Labour supply & Reduction of work effort \\
\hline 55 & $\begin{array}{l}\text { Maynard, } \\
1977[66]\end{array}$ & RIME & NIT & USA & School performance & $\begin{array}{l}\text { Improvements in school performance; Increases } \\
\text { in educational attainment. }\end{array}$ \\
\hline 56 & $\begin{array}{l}\text { Maynard and } \\
\text { Murnane, } \\
1979[113]\end{array}$ & Gary & NIT & USA & School performance & $\begin{array}{l}\text { Increase in average reading achievement for } \\
\text { grades } 4-6\end{array}$ \\
\hline 57 & $\begin{array}{l}\text { McDonald } \\
\text { and } \\
\text { Stephenson, } \\
1979[114]\end{array}$ & Gary & NIT & USA & School enrollment & $\begin{array}{l}\text { Being males increased rate of school enrollment } \\
\text { and reduced labor force participation }\end{array}$ \\
\hline 58 & $\begin{array}{l}\text { Metcalf, } 1973 \\
{[57]}\end{array}$ & $\begin{array}{l}\text { US IMES } \\
\text { (not } \\
\text { specified) }\end{array}$ & NIT & USA & $\begin{array}{l}\text { Temporary NIT results extended to } \\
\text { permanent NIT results }\end{array}$ & $\begin{array}{l}\text { A temporary experiment will 1) understate the } \\
\text { income effect and 2) overstate the gross and } \\
\text { compensated price effects of the NIT. }\end{array}$ \\
\hline
\end{tabular}


Table 2 Data Extraction Outcomes (Continued)

\begin{tabular}{|c|c|c|c|c|c|c|}
\hline No & $\begin{array}{l}\text { Authors, } \\
\text { Year }\end{array}$ & $\begin{array}{l}\text { Basic } \\
\text { Income } \\
\text { Experiment }\end{array}$ & $\begin{array}{l}\text { Type of Basic } \\
\text { Income }\end{array}$ & Country & Main Outcome & Main Outcome Results \\
\hline 59 & $\begin{array}{l}\text { Moffitt, } 1979 \\
{[115]}\end{array}$ & Gary & NIT & USA & $\begin{array}{l}\text { Employment status and unconditional } \\
\text { hours worked }\end{array}$ & $\begin{array}{l}\text { Labor supply reductions for husbands and } \\
\text { female heads, but not for wives }\end{array}$ \\
\hline 60 & $\begin{array}{l}\text { Moffitt, } 1981 \\
\text { [71] }\end{array}$ & $\begin{array}{l}\text { NJ, RIME, } \\
\text { Gary, SIME/ } \\
\text { DIME }\end{array}$ & NIT & USA & Weekly work hours & Reduced weekly work hours \\
\hline 61 & $\begin{array}{l}\text { Moffit and } \\
\text { Kehrer, } 1981 \\
{[75]}\end{array}$ & $\begin{array}{l}\text { NJ, RIME, } \\
\text { Gary, SIME/ } \\
\text { DIME }\end{array}$ & NIT & USA & Weekly work hours & Reduced weekly work hours \\
\hline 62 & $\begin{array}{l}\text { Munnell } \\
\text { et al., } 1987 \\
{[116]}\end{array}$ & $\begin{array}{l}\text { NJ, RIME, } \\
\text { Gary, SIME/ } \\
\text { DIME }\end{array}$ & NIT & USA & $\begin{array}{l}\text { The effect of the NIT Treatments on } \\
\text { Work Effort and Labour Supply }\end{array}$ & Reduction in work effort for most subsamples \\
\hline 63 & $\begin{array}{l}\text { Murray and } \\
\text { Pateman, } \\
2012[67]\end{array}$ & MINCOME & NIT & Canada & High school continuation & $\begin{array}{l}\text { Adolescent males did continue in high school } \\
\text { longer }\end{array}$ \\
\hline 64 & $\begin{array}{l}\text { Neuberg, } \\
1988[62]\end{array}$ & SIME/DIME & NIT & USA & Distortion in reporting hours worked & Distortion revealed in reporting hours worked \\
\hline 65 & $\begin{array}{l}\text { Nicholson } \\
\text { and Wright } \\
1977[37]\end{array}$ & NJ & NIT & USA & Participants' understanding of the NIT & $\begin{array}{l}\text { The NIT was not well understood by } \\
\text { experimental participants }\end{array}$ \\
\hline 66 & $\begin{array}{l}\text { O'Connor } \\
\text { and Madden, } \\
1979 \text { [117] }\end{array}$ & RIME & NIT & USA & Diet & $\begin{array}{l}\text { Little, if any, influence on the quality of the } \\
\text { diets of the lowa families; evidence of a } \\
\text { beneficial effect on the quality of the diets of } \\
\text { the North Carolina families. }\end{array}$ \\
\hline 67 & $\begin{array}{l}\text { Osterkamp, } \\
2013[78]\end{array}$ & $\begin{array}{l}\text { BIG } \\
\text { Coalition } \\
\text { (Namibia) }\end{array}$ & $\begin{array}{l}\text { Universal } \\
\text { Unconditional } \\
\text { Cash Transfer }\end{array}$ & Namibia & Poverty reduction & Poverty was substantially reduced \\
\hline 68 & $\begin{array}{l}\text { Robins, } 1980 \\
{[38]}\end{array}$ & SIME/DIME & NIT & USA & $\begin{array}{l}\text { The effect of the NIT treatments on } \\
\text { the labor supply of youth }\end{array}$ & $\begin{array}{l}\text { The effect of the NIT Treatments on the Labor } \\
\text { Supply of Youth }\end{array}$ \\
\hline 69 & $\begin{array}{l}\text { Robins, } 1985 \\
{[118]}\end{array}$ & $\begin{array}{l}\text { NJ, RIME, } \\
\text { Gary, SIME/ } \\
\text { DIME }\end{array}$ & NIT & USA & Labour supply & Labour supply reduced \\
\hline 70 & $\begin{array}{l}\text { Robins, } \\
\text { Tuma, and } \\
\text { Yaeger, } 1980 \\
\text { [119] }\end{array}$ & SIME/DIME & NIT & USA & $\begin{array}{l}\text { Rates of leaving and entering } \\
\text { employment }\end{array}$ & $\begin{array}{l}\text { Higher rate of leaving employment and lower } \\
\text { rate of entering employment }\end{array}$ \\
\hline 71 & $\begin{array}{l}\text { Robins and } \\
\text { West, } 1986 \\
{[120]}\end{array}$ & SIME/DIME & NIT & USA & $\begin{array}{l}\text { Impacts of accounting differences } \\
\text { between study attriters and non- } \\
\text { attriters on employment and earnings } \\
\text { estimates }\end{array}$ & $\begin{array}{l}\text { Weighting techniques that considered } \\
\text { differences between attriters and non-attriters } \\
\text { did not have significant impact on the employ- } \\
\text { ment and earnings estimates }\end{array}$ \\
\hline 72 & $\begin{array}{l}\text { Ross, } 1970 \\
{[121]}\end{array}$ & NJ & NIT & USA & Work Disincentive Effects & No evidence of work disincentive response \\
\hline 73 & $\begin{array}{l}\text { Rossi and } \\
\text { Rosenbaum, } \\
1983[77]\end{array}$ & NJ & NIT & USA & Work effort & Work effort declined slightly \\
\hline 74 & $\begin{array}{l}\text { Salkind and } \\
\text { Haskins, } 1982 \\
{[50]}\end{array}$ & $\begin{array}{l}\text { NJ, RIME, } \\
\text { Gary, SIME/ } \\
\text { DIME }\end{array}$ & NIT & USA & Fertility, nutrition, birth weight & $\begin{array}{l}\text { Lower fertility; quality of nutrition increased; } \\
\text { Fewer low birth weight babies }\end{array}$ \\
\hline 75 & $\begin{array}{l}\text { Skidmore, } \\
1974[46]\end{array}$ & NJ & NIT & USA & None & $\begin{array}{l}\text { None (paper only describes the type of data } \\
\text { that are available from the experiment) }\end{array}$ \\
\hline 76 & $\begin{array}{l}\text { Spiegelman } \\
\text { and Yaeger, } \\
1980[83]\end{array}$ & SIME/DIME & NIT & USA & Labor supply & $\begin{array}{l}\text { Husbands and single-family heads left employ- } \\
\text { ment more readily }\end{array}$ \\
\hline 77 & $\begin{array}{l}\text { Standing, } \\
2015[122]\end{array}$ & India & $U \subset T$ & India & Debt & $\begin{array}{l}\text { Less likely to increase debt and more likely to } \\
\text { reduce it }\end{array}$ \\
\hline 78 & $\begin{array}{l}\text { Stephens, } \\
2007[123]\end{array}$ & SIME/DIME & NIT & USA & $\begin{array}{l}\text { Work hours for men in dual-headed } \\
\text { households }\end{array}$ & $\begin{array}{l}\text { Hours of work reduction for men in dual- } \\
\text { headed households was greater for the } 5 \text {-year }\end{array}$ \\
\hline
\end{tabular}


Table 2 Data Extraction Outcomes (Continued)

\begin{tabular}{|c|c|c|c|c|c|c|}
\hline No & $\begin{array}{l}\text { Authors, } \\
\text { Year }\end{array}$ & $\begin{array}{l}\text { Basic } \\
\text { Income } \\
\text { Experiment }\end{array}$ & $\begin{array}{l}\text { Type of Basic } \\
\text { Income }\end{array}$ & Country & Main Outcome & Main Outcome Results \\
\hline & & & & & & experiment than the 3 -year one \\
\hline 79 & $\begin{array}{l}\text { Watts, } 1969 \\
{[124]}\end{array}$ & NJ & NIT & USA & Participation & $\begin{array}{l}\text { Almost all of those who have been invited to } \\
\text { participate in the payments program have } \\
\text { chosen to do so }\end{array}$ \\
\hline 80 & $\begin{array}{l}\text { Weiss, Hall, } \\
\text { and Dong, } \\
1980[125]\end{array}$ & SIME/DIME & NIT & USA & Schooling investment & Increase in schooling investment \\
\hline 81 & $\begin{array}{l}\text { West, } 1980 \\
{[126]}\end{array}$ & SIME/DIME & NIT & USA & Wage rates & Little basis to indicate any effect on wage rates \\
\hline 82 & $\begin{array}{l}\text { West, } 1980 \\
\text { [127] }\end{array}$ & SIME/DIME & NIT & USA & $\begin{array}{l}\text { Work effort among non-heads of } \\
\text { families }\end{array}$ & Reduction in work effort among non-heads \\
\hline 83 & $\begin{array}{l}\text { Widerquist, } \\
2005 \text { [51] }\end{array}$ & $\begin{array}{l}\text { NJ, RIME, } \\
\text { Gary, SIME/ } \\
\text { DIME, } \\
\text { MINCOME }\end{array}$ & NIT & $\begin{array}{l}\text { USA } \\
\text { and } \\
\text { Canada }\end{array}$ & Work-effort reduction & Work-effort reduced \\
\hline 84 & $\begin{array}{l}\text { Widerquist, } \\
2013[128]\end{array}$ & $\begin{array}{l}\text { NJ, RIME, } \\
\text { Gary, SIME/ } \\
\text { DIME, } \\
\text { MINCOME }\end{array}$ & NIT & $\begin{array}{l}\text { USA } \\
\text { and } \\
\text { Canada }\end{array}$ & Work Disincentive Results & $\begin{array}{l}\text { Longer periods of nonemployment or return to } \\
\text { work }\end{array}$ \\
\hline 85 & $\begin{array}{l}\text { Wright and } \\
\text { Wright, } 1975 \\
\text { [129] }\end{array}$ & NJ & NIT & USA & Labour force participation & No difference in incentive to work \\
\hline 86 & $\begin{array}{l}\text { Wright, } 1975 \\
\text { [39] }\end{array}$ & NJ & NIT & USA & Work disincentive effects & $\begin{array}{l}\text { No statistically significant work disincentive } \\
\text { effects }\end{array}$ \\
\hline
\end{tabular}

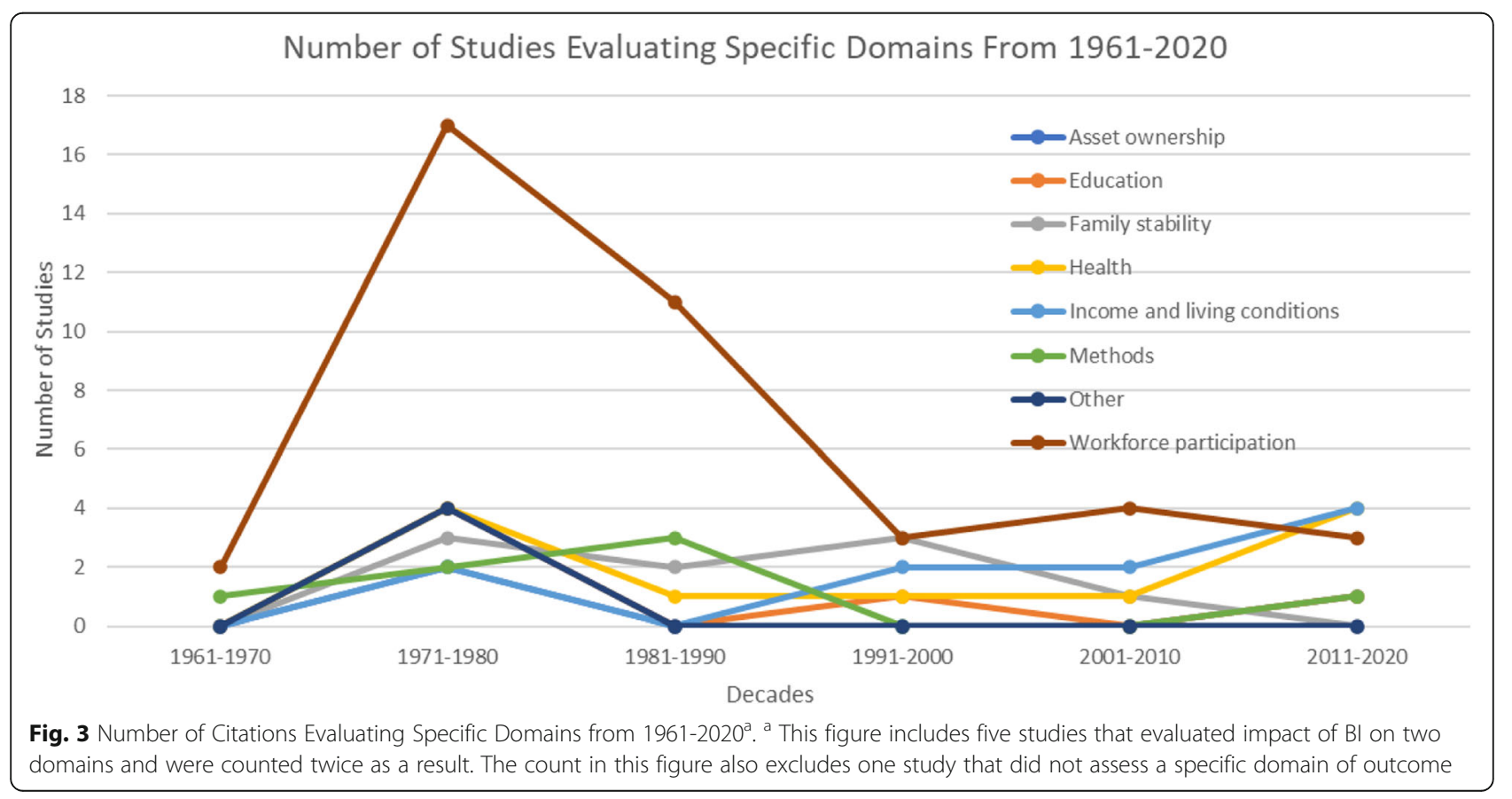


interviews. The MINCOME experiment ended data collection after the third round of interviews. The MPUCT experiment was unique in their utilization of evaluation-based surveys that were administered at interim, final and postfinal time points.

Each experiment utilized a wide array of data sources to gather information on the participants' eligibility to receive benefits, their demographics, and the outcome of interests. There was a concern about underreporting of income during the BI experiments using the NIT model, particularly among participants in the treatment arm, given the amount of benefit that they were eligible for would decrease as their income increased [62]. To address this concern, several BI experiments involved multiple forms of income substantiation to determine the amount of benefits that the participants were able to claim. Compared to other US-based interventions, the NJ held the most robust income data collection method, as information was gathered using income data forms, pay stubs, social security aggregate data and periodic audit forms. In contrast, Gary and RIME only utilized self-reported income information and periodic audit forms (Table 1). Additional data sources that were included during the BI experiments in the US included family composition reporting and social- and health-related organizations.

Nine articles complemented the data that was collected during the duration of the BI experiment with other data sources. In most cases, this involved administrative data that provided further information on the specific domain in question. For example, a study examining the impact of NIT on birth weight utilized data taken from the Indiana's certificate of birth [63]. Other studies also triangulated survey or interview data with administrative data related to health $(n=2)$, school performance and resources $(\mathrm{n}=2)$, and employment and income level $(n=3)$, while another study combined data taken from multiple population-based surveys to examine employment rate $(n=1)[10,42,54,56,64-67]$.

No specific income-based data sources were listed for MINCOME; however, information was gathered using the Manitoba Population Health Research Data Repository Database along with information from the Department of Education. Similarly, no income-specific data source was reported in the preliminary findings of the Finnish experiment, although administrative data capturing indicators of work effort response was supplemented with analysis on survey data to measure a number of health outcomes. Comparably, the MPUCT, Namibian and Kenyan projects did not mention income-specific data sources utilized. Rather, each experiment included interviews with key informants such as local stakeholders, local leaders, shopkeepers, village dwellers, as well as health care providers and police chiefs [36, 40, 53]. Both MPUCT and the Give Directly Unconditional
Cash Transfer program collected measurements on children's weight. A unique aspect of the Namibian BIG project included its incorporation of case studies relating to outcomes [40]. The use of these case studies provides valuable context on the poverty in the region and the living conditions of the participants before the BIG intervention, the participants' expectations for the intervention, and how the intervention compared to their expectations.

The evaluation approach of the Alaskan Permanent Fund Dividend is different from those employed in other studies. Jones and Marinescu [42] used the employment to population ratio and the share of the population working part-time when comparing the evolution of labour market outcomes in Alaska before and after the introduction of the dividend payments. The observed data were divided into pre-dividend years, covering July 1979 up to the introduction of dividend payment in June 1982, and post-dividend years from July 1982 to June 2015. All outcomes of the study were measured through analysis of existing survey data, namely the Current Population Survey.

There were 64 studies in this review that either analyzed data collected during the BI experiments or proposed a specific approach of analysis, with most of them adopting some form of multi-variate statistical modelling $(n=60)$ in their analyses, while other studies conducted bivariate $(n=6)$ or univariate analysis $(n=9)$. Economic modelling and simple regressions were the two most used statistical models, accounting for utilization in 53 studies. Other statistical models that were used include difference in differences, path analysis model, principal components analysis, time series model, structural equation modelling and root-mean squared error.

Finally, some authors of the included articles discussed important elements that need to be considered when implementing and evaluating the impact of a $\mathrm{BI}$ intervention $(n=23)$, and some common themes emerged. Inaccurate reporting, such as underreporting of income streams among the treatment group and inability to recall past experiences, was the most common consideration highlighted by the authors $(n=9)$. High rate of attrition was also cited as a common issue that was encountered during longitudinal BI programs that lasted for several years $(n=7)$. The next common consideration was related to recruitment $(n=6)$. For example, a study examining the MPUCT program in India emphasized the importance of cluster-level randomization to mimic the universality of $\mathrm{BI}$ and to prevent distortion of BI effects that can be delivered through community-level mechanism [45]. Two studies underscored the need to select control and treatment populations with comparable characteristics to avoid inaccurate estimation of BI effects due to unaccounted confounding variables [38, 
68]. Several researchers also cautioned against extrapolating the results of a single BI experiment to the national level, considering the differences in the population characteristics, local policies, and the existing welfare systems $(n=4)$ [38, 69-71]. In addition, some authors discussed the potential attenuation or exaggeration of the $\mathrm{BI}$ impacts due to the temporary nature of the BI experiments, which could influence participants to behave differently than if the intervention were longer or permanent $(n=3)$ [71-73]. Other important considerations that were discussed include the high cost of running a BI intervention, which can pose a challenge for replication $[44,74,75]$; the relatively rare instances of outcome of interests such as divorce that can influence the reliability of the estimates $[38,72,75]$; community influence on the acceptance of BI [76, 77]; and the importance of selecting an appropriate method for transferring the fund to accommodate participants who may not have access to a bank account [76].

\section{Discussion}

In summary, 86 studies that spoke to 10 types of BI experiments were identified. The studies were diverse in nature and occurred within the past six decades. Our analysis revealed several consistent elements of the BI evaluation methods despite geographical differences. Most of the BI experiments implemented RCT design and randomized the sample selection at household or individual levels. Two BI experiments in rural settings, the MPUCT in India and the Give Directly Unconditional Cash Transfer Program in Kenya adopted clusterrandomized controlled trials, where randomizations occurred at the village-level. The advantage of this approach is its ability to mirror a universal basic income program where everybody receives an income and to capture any effects of basic income that are operated through community-level mechanisms and are facilitated by behavioural adaptation $[45,76]$. However, this approach must take into account the higher degree of similarities among individuals within a cluster relative to those between different clusters.

The Namibian BIG Project and the Alaska Permanent Dividend Fund used observational design to evaluate the impact of BI. The BIG project was a pilot study aimed to move forward the nation's discussion around basic income and therefore chose to observe only one village that was manageable in size and experienced a high degree of poverty [78]. In contrast, the Alaskan Permanent Dividend Fund is a state-funded program that has been running for almost 4 decades. The study examining this program utilized census and population-based survey data and chose difference-in-differences (DiD) analysis approach that allows for comparison between a group that is exposed to a treatment and another unexposed group, while taking into account differences that already exist prior to the treatment [42]. By employing this approach, researchers were able to both examine the evolution of the labour market in Alaska prior to and following the introduction of the dividend fund and compare it against the changes in labour market in other states that did not implement a similar program. Because of its large scale and the need to accumulate longitudinal data that can span over decades, this type of study is hard to replicate, particularly in a setting that does not have a reliable system to maintain population data. This approach also requires careful selection of other locations that are comparable in its population characteristics to serve as appropriate controls.

Various debates have emerged that discuss the effectiveness of study designs used in the evaluation of BI experiments. Widerquist [79] argues that due to their narrow focus and context, controlled, small-scale experiments have limited ability in uncovering the potential benefits of BI. The experiments included in this study involved relatively large numbers of participants and collected longitudinal data that spanned over several years and touched on various domains. The large sample size is important in producing reliable results with a high degree of precision and power, especially when differences between populations were assessed. Other researchers contend that conventional RCTs which account for the majority of experiments included in this review may not be an appropriate approach for demonstrating the effectiveness of BI. Scholars argue that the provision of income to a randomized cohort of individuals overlooks the influence of structural factors on BI-related outcomes [80]. These structural factors include social norms, role modeling, business responses, collective action and work for the underemployed [80]. In light of this, future BI experiments can consider other designs, such as clustered RCT or other longitudinal study designs that provide $\mathrm{BI}$ to all members of a specific cluster, such as a neighbourhood or a city [80,81].

Overall, the studies placed a particular focus on labour-related outcomes, which included job searching attitudes and hours worked. Additional outcomes included impact on marital stability and dissolution, educational investments and outcomes, awareness of social services, level of debt, wage, and home ownership. A few studies $(n=11)$ analyzed the impact of BI on healthrelated outcomes as their main outcomes, including hospitalization. In many cases, the methods and outcomes were driven by the time period in which the BI experiments were conducted. In the 1960's and 70's, a strong focus was placed on the impact of BI on labour activities while more recent literature has incorporated a more holistic picture of BI's impacts on factors such as social connectedness, health outcomes and education. 
The shift in focus towards health and education outcomes in studies dated after the 1990's may be attributed to the societal recognition of the importance of the social determinants of health $[7,8,13,14]$.

Almost all studies used self-reported data, which was collected using surveys administered in person serially, complemented with administrative data. The common use of surveys in BI experiments was also noted in another review [27]. Several evidences have emerged on potential reporting bias due to underreporting of level of income and employment among the treatment group, particularly when the amount of benefits received is dependent on their income level [56, 82]. Recall bias is also a potential issue that researchers must contend with when using self-reported information. The SIME/DIME experiment, for example, asked participants to recall income information from the previous 4 months and more recent events may influence their perspectives and subsequent responses [83]. Therefore, data from alternative sources, such as unemployment insurance agencies or tax reports can be considered in future BI experiments to ensure accurate information. Appropriate training for interviewers and clear reporting forms are also potential measures to consider for reliable data collection [84].

When designing a BI experiment, researchers will need to consider the sample size of individuals who present their outcomes of interest. A study focusing on marital dissolution, for example, explained that their analytical approach must address the issue of small number of divorce occurrences to reliably measure the relationship between BI and divorce rates [72]. High rates of attrition, particularly in longitudinal studies spanning over a number of years, can also reduce the effective sample size and introduce bias if there are differential attrition rates between the control and the experimental groups, or if there is a fundamental difference in the characteristics of the participants who drop out and those who remain [74, 84]. Furthermore, future BI experiments could assess the dose-specific effects of income subsidy on the population, as was done during the NJ experiment that collected behaviour data from a sample that was given various amount of benefits [85].

The local resources to support the BI experiments will also need to be carefully considered, particularly when they are implemented in a rural area with limited access to technology. The MPUCT in India described difficulties in providing cash to participants as the majority of households did not have bank accounts, and physical transfer of funds proved to be challenging given the remote and hard to reach location of the experiment site [76]. Finally, existing presence of social agencies in the communities and local policies around social welfare may also influence the take-up rate of the BI intervention, and any attempt to compare experimental and control sites must consider these differences $[76,77]$.

This systematic review provides various implications for future research and intervention implementation related to BI. Primarily, this review has identified what previous evaluations of BI interventions have used as outcome measures when determining overall effectiveness. Identifying these outcomes not only provides a basis for future research, but also identifies existing gaps in knowledge with respect to the assessment of BI interventions (e.g., how does BI influence rates of violence?). Moving beyond the identification of common outcome measures, methods which have been incorporated in evaluations of BI interventions have been identified. This again provides future researchers or program implementers information on how to meaningfully evaluate a BI intervention. This systematic review demonstrates the range of impact BI interventions have on individuals, all of which contribute to overall health and well-being. However, the findings also outline common challenges that may be faced when assessing a BI intervention, including cost, which again can assist in developing pragmatic evaluation strategies.

This review has a number of strengths. It is the first systematic review to focus on the methodology used to evaluate $\mathrm{BI}$ in numerous experiments. All studies in this field from all countries were included and the similarities and differences on various aspects of their methodology were described. This review also has limitations. First, experiments with conditional cash transfers (e.g., Brazil's Bolsa Familia, Italy's Sostegno per l'Inclusione Attiva, and Uganda's Youth Opportunities Programs) were not included. BI experiments that were still in the planning phases or had been prematurely cancelled (e.g., in Scotland, the Netherlands and Ontario, Canada) were excluded. Our study's exclusion of qualitative methods of evaluation limited its insight on individual's perceptions of BI. Furthermore, the inconsistency in the reporting of methods, which can be attributed to the wide array of included studies, poses a challenge in determining the effectiveness of specific methods.

\section{Conclusions}

Income represents a key social determinant of health, which aids in the attainment of employment and maintenance of health and well-being [86]. The implementation of BI studies are particularly unique in that they are shaped by the policy priorities of the government in power. Research and interest in BI will continue to grow as states recognize that the current models of welfare are inadequate, overly bureaucratic and lead to further harms due to welfare-state conditions. The current social, health and political climate that has developed as a result of the COVID-19 pandemic, presents a unique 
opportunity to discuss the impacts of $\mathrm{BI}$ on overall health and well-being. This systematic review provides future researchers and program developers the tools needed to develop and evaluate $\mathrm{BI}$ as a method of social intervention effectively.

As identified by this review, there are various outcome measures and methods that have been implemented to evaluate existing $\mathrm{BI}$ interventions. Moving beyond the integration of RCTs, future research in this area should evaluate the rationale for different methodological approaches, while considering novel methods used to capture individual-level data, including through administrative data linkage. Additional methods that should be assessed in relation to BI intervention evaluations include the use of qualitative methods. Completing accurate and rigorous evaluations of social interventions, such as $\mathrm{BI}$, will not only ensure that effective programmatic and policy-level changes occur, but will also aid in the improvement of the health and well-being of various populations.

\section{Abbreviations \\ BI: Basic Income; COVID-19: Coronavirus Disease of 2019; Gary: Gary Income Maintenance Experiment; IME: Income Maintenance Experiments; MPUCT: Madhya Pradesh Unconditional Cash Transfer Project; NIT: Negative Income Tax; NJ: New Jersey Income Maintenance Experiment; RCT: Randomized Controlled Trial; RIME: Rural Income Maintenance Experiment; SIME/DIME: Seattle-Denver Income Maintenance Experiment; UCT: Unconditional Cash Transfers; US: United States}

\section{Supplementary Information}

The online version contains supplementary material available at https://doi. org/10.1186/s12939-021-01479-2.

Additional File 1. Search Strategy and List of Searched Databases. Additional File 2. Assessment of Quality of Individual Articles.

\section{Acknowledgements}

This study was supported by funding from the St. Michael's Hospital Foundation. AP is supported as a Clinician Scientist by the Department of Family and Community Medicine, Faculty of Medicine, University of Toronto, the Department of Family and Community Medicine, St. Michael's Hospital, and the Li Ka Shing Knowledge Institute, St. Michael's Hospital. AP is also supported by a fellowship from the Physicians' Services Incorporated Foundation and as the Associate Director for Clinical Research at the University of Toronto Practice-Based Research Network (UTOPIAN). We would also like to thank Julia Ho who supported the research team in the quality assessment process and Carolyn Ziegler for supporting the literature search. Finally, we would like to thank the diligent systematic review team who reviewed abstracts and full-text articles and conducted the data extraction. These team members included Bethel Aklilu, Rebecca Brown, Whitney Dang, and Annika Khan.

\section{Authors' contributions}

$\mathrm{AP}, \mathrm{SH}, \mathrm{TA}$, and CP contributed to the conception and design of the study. Manuscript was drafted by $\mathrm{AP}, \mathrm{MP}, \mathrm{AH}$, and $\mathrm{CP}$. All authors provided critical revisions to the manuscript. The author(s) read and approved the final manuscript.

\section{Funding}

This study was supported by funding from the St. Michael's Hospital Foundation. The funder of the study had no role in study design, data collection, data analysis, data interpretation, or writing of the report. The corresponding author had full access to all the data in the study and had final responsibility for the decision to submit for publication.

Availability of data and materials

Data sharing is not applicable to this article as no datasets were generated or analyzed during the current study.

\section{Declarations}

Ethics approval and consent to participate

Not applicable.

Consent for publication

Not applicable.

\section{Competing interests}

The authors declare that they have no competing interests.

\section{Author details}

'MAP Centre for Urban Health Solutions, Li Ka Shing Knowledge Institute, Unity Health Toronto, Toronto, Canada. ${ }^{2}$ Department of Family and Community Medicine, St. Michael's Hospital, Toronto, Canada. ${ }^{3}$ Department of Family and Community Medicine, Faculty of Medicine, University of Toronto, Toronto, Canada. ${ }^{4}$ Dalla Lana School of Public Health, University of Toronto, Toronto, Canada. ${ }^{5}$ Division of General Internal Medicine, Department of Medicine, University of Toronto, Toronto, Canada.

Received: 20 October 2020 Accepted: 24 May 2021

Published online: 16 June 2021

\section{References}

1. Niessen LW, Mohan D, Akuoku JK, Mirelman AJ, Ahmed S, Peters DH, et al. Tackling socioeconomic inequalities and non-communicable diseases in low-income and middle-income countries under the Sustainable Development agenda. Lancet. 2018;391:2036-82 [cited 2020 Dec 30]. Available from: http://dx.doi.org/10.1016/

2. Pickett KE, Wilkinson RG. Income inequality and health: A causal review. Vol. 128, Social Science and Medicine. Elsevier Ltd; 2015. p. 316-26.

3. Lin KH, Tomaskovic-Devey D. Financialization and U.S. income inequality. Am J Sociol. 2013;118(5):1284-329. https://doi.org/10.1086/669499.

4. Fletcher DR. Welfare reform, Jobcentre plus and the street-level bureaucracy: towards inconsistent and discriminatory welfare for severely disadvantaged groups? Soc Policy Soc. 2011 Oct 1;10(4):445-58. https://doi. org/10.1017/S1474746411000200

5. $\quad$ Albeda W. The dream of a humane capitalism. Maandschr Econ. 1999;63(6): 406-26

6. Pelton LH. Welfare Discrimination and Child Welfare. Ohio State Law J. 1999 60 [cited 2020 Jun 9]. Available from: https://heinonline.org/HOL/Page?ha ndle=hein.journals/ohsli60\&id $=1493 \&$ div $=43 \&$ collection=journals.

7. Ruckert A, Huynh C, Labonté R. Reducing health inequities: is universal basic income the way forward? J Public Health (Bangkok). 2018;40(1):3-7 [cited 2020 Dec 30]. Available from: https://academic.oup.com/jpubhealth/article/4 0/1/3/2966187.

8. Painter A. A universal basic income: the answer to poverty, insecurity, and health inequality? BMJ. 2016;355(December):1-2

9. Ontario Ministry of Community and Social Services. Basic income pilot: public survey. 2016 [cited 2017 Jan 4]. Available from: https://www.ontario. $\mathrm{ca} /$ form/basic-income-pilot-public-survey

10. Forget EL. The Town with No Poverty: the health effects of a Canadian guaranteed annual income field experiment. Can Public Policy. 2011;37(3): 283-305.

11. Forget EL, Marando D, Surman T, Urban MC. Pilot lessons: how to design a basic income pilot project for Ontario; 2016

12. Standing G. From cash transfers to basic income: an unfolding Indian agenda. Indian J Labour Econ. 2014;57(1):111-38 Available from: http:// www.guystanding.com/files/documents/IJLE_cash_transfers_basic_ income 2014 as published.pdf\%5Cnpapers2://publication/uuid/3D07D3C46167-47E9-8012-ABE98C78D8F2.

13. Navarro $V$. What we mean by social determinants of health. Glob Health Promot. 2009;16(1):5-16. https://doi.org/10.1177/1757975908100746. 
14. Muntaner C, Salazar RMG, Rueda S, Armada F. Challenging the neoliberal trend. Can J Public Heal. 2006;97(6):119-24. https://doi.org/10.1007/BF034 05240.

15. Harvey D. A brief history of neoliberalism. New York: Oxford University Press; 2007.

16. Dermont $C$, Weisstanner D. Automation and the future of the welfare state: basic income as a response to technological change? Polit Res Exch. 2020; 2(1):1757387 [cited 2020 Dec 30]. Available from: https://www.tandfonline. com/action/journallnformation?journalCode=prxx20.

17. Celentano D. Automation, Labour Justice, and Equality. Ethics Soc Welf. 2019;13(1):33-50 [cited 2020 Dec 30]. Available from: https://www.ta ndfonline.com/action/journallnformation?journalCode=resw20.

18. Shah M, Sachdeva M, Dodiuk-Gad RP. COVID-19 and racial disparities. J Am Acad Dermatol. 2020;83(1):e35. https://doi.org/10.1016/j.jaad.2020.04.046.

19. Dyer O. Covid-19: Africa records over 10000 cases as lockdowns take hold. BMJ. 2020;369(March):m1439. Available from:. https://doi.org/10.1136/bmj. m1439.

20. Usher K, Bhullar N, Jackson D. Life in the pandemic: social isolation and mental health. J Clin Nurs. 2020 Aug 1;29(15-16):2756-7. https://doi.org/1 $0.1111 /$ jocn.15290

21. Slater A. The economic cost of coronavirus lockdowns Economist [Internet]. [cited 2020 Dec 31]. Available from: https://www.economics.ox.ac.uk/materia Is/working_papers/p

22. Gounder R. Economic vulnerabilities and livelihoods: impact of COVID-19 in Fiji and Vanuatu. Oceania. 2020;90(Suppl. 1): 107-13.

23. Employment and Social Development of Canada. Government of Canada announces plan to help support Canadians through the next phase of the recovery - Canada.ca [Internet]. [cited 2020 Dec 31]. Available from: https:// www.canada.ca/en/employment-social-development/news/2020/08/ government-of-canada-announces-plan-to-help-support-canadians-throughthe-next-phase-of-the-recovery.htm

24. Treasury T. COVID-19 economic response measures [Internet]. [cited 2020 Dec 31]. Available from: https://www.treasury.govt.nz/information-andservices/new-zealand-economy/covid-19-economic-response/measures

25. Johnson AF, Roberto KJ. The COVID-19 pandemic: time for a universal basic income? 2020 [cited 2020 Dec 31]; Available from: https://orcid.org/00000003-4041-3494

26. Ståhl C, MacEachen E. Universal Basic income as a policy response to COVID-19 and precarious employment: potential impacts on rehabilitation and return-to-work. J Occup Rehab. Springer. 2020:1-4 [cited 2020 Dec 31]. https://doi.org/10.1007/s10926-020-09923-w.

27. Gibson M, Hearty W, Craig P. Potential effects of universal basic income: a scoping review of evidence on impacts and study characteristics. Lancet. 2018;392:S36.

28. Aboudi R, Thon D, Zheng M. Designing a basic income system with a social welfare function. J Public Econ Theory. 2014;16(4):546-68. https://doi.org/1 $0.1111 /$ jpet.12074.

29. Fitzpatrick T, Rosella LC, Calzavara A, Petch J, Pinto AD, Manson H, et al. Looking beyond income and education: socioeconomic status gradients among future high-cost users of health care. Am J Prev Med. 2015;49(2): 161-71. Available from: http://linkinghub.elsevier.com/retrieve/pii/S07493 79715000823. https://doi.org/10.1016/j.amepre.2015.02.018.

30. Rosella LC, Fitzpatrick T, Wodchis WP, Calzavara A, Manson H, Goel V. High-cost health care users in Ontario, Canada: Demographic, socioeconomic, and health status characteristics. BMC Health Serv Res. 2014;14(1):532. Available from: http://www.biomedcentral.com/1472$6963 / 14 / 532$

31. Commission on Social Determinants of Health. Closing the gap in a generation. Health Equity Through Action on the Social Determinants of Health. Geneva: World Health Organization; 2008. https://doi.org/10.1186/ s12939-021-01479-2

32. Canadian Institute for Health Information. Trends in Income-Related Health Inequalities in Canada. 2015;1692(November):1998-2011.

33. Green D, Kesselman JR, Tedds L. Consideration for basic income as a Covid19 response. Sch Public Policy Publ. 2020;13(11):1-15 [cited 2020 Dec 31]. Available from: https://doi.org/10.11575/sppp.v13i0.70353.

34. Mourão L, de Jesus AM. Bolsa família (Family Grant) programme: An analysis of Brazilian income transfer programme. F Actions Sci Rep. 2012;4(Special Issue 4):43-9.

35. Joanna Briggs Institute (JBI). Critical Appraisal Tools. [cited 2021 Apr 2] Available from: https://jbi.global/critical-appraisal-tools
36. Haushofer J, Shapiro J. Household Response to Income Changes: Evidence from an Unconditional Cash Transfer Program in Kenya. 2013. Available from: https://www.poverty-action.org/publication/household-responseincome-changes-evidence-unconditional-cash-transfer-program-kenya

37. Nicholson W, Wright SR. Participants' understanding of the treatment in policy experimentation. Eval Q. 1977 May;1(2):245-68. https://doi.org/10.11 77/0193841X7700100202.

38. Robins PK. A Guaranteed annual income: evidence from a social experiment. New York: Academic Press; 1980. [cited 2020 Jun 10]. Available from: https://search.library.utoronto.ca/details?4235333

39. Wright S. Work response to income maintenance: economic, sociological, and cultural perspectives. Soc Forces. 1975;53(4):562.

40. Haarmann C, Haarmann D, Jauch $\mathrm{H}$, Shindondola-Mote $H$, Nattrass $\mathrm{N}$, Samson M, et al. "Towards a basic income grant for all": Basic income grant pilot project assessment report. Windhoek: Basic Income Grant Coalition; 2008

41. Haarmann $\mathrm{C}$, Haarmann D, Jauch $\mathrm{H}$, Shindondola-Mote $H$, Nattrass $N$, van Niekerk I, et al. Making the difference! The BIG in Namibia Basic Income Grant Pilot Project. 2009 [cited 2020 Jun 10]. Available from: http://www. bignam.org/Publications/BIG_Assessment_report_08b.pdf

42. Jones D, Marinescu I. The labour market impacts of universal and permanent cash transfers: evidence from the Alaksa permanent fund [Internet]. Working Paper 24312, Journal of Chemical Information and Modeling. Cambridge; 2018. Available from: http://www.nber.org/papers/ w24312\%0ANATIONAL. Accessed 16 June 2020.

43. Moffitt RA. The negative income tax and the evolution of U.S. welfare policy. J Econ Perspective. 2003;17(3):119-40.

44. Connor J, Rodgers A, Priest P. Randomised studies of income supplementation: a lost opportunity to assess health outcomes. J Epidemiol Commun Health. 1999:53(11):725-30. Available from: https://www.scopus. $\mathrm{com} /$ inward/record.uri?eid=2-s2.0-0032845839\&partnerlD=40\&md5=08b91 7e6e8875312d1e84adc6c9f367e. https://doi.org/10.1136/jech.53.11.725.

45. Beck S, Pulkki-Brannstrom AM, San SM. Basic income - healthy outcome? Effects on health of an Indian basic income pilot project: a cluster randomised trial. J Dev Eff. 2015;7(1):111-26. https://doi.org/10.1080/1943 9342.2014.974200.

46. Skidmore F. Availability of data from the graduated work incentive experiment. J Hum Resour. 1974;9(2):265-78. https://doi.org/10.2307/144976.

47. U.S. Department of Health, Education and Welfare. The Rural Income Maintenance Experiment [Internet]. Vol. 3, Evaluation Studies Review Annual. Beverly Hills: Sage Publications; 1978.

48. Bawden DL. Income maintenance and the rural poor: an experimental approach. Am J Agric Econ. 1970 Aug;52(3):438-41. https://doi.org/10.23 07/1237396.

49. Kaluzny RL. Changes in the consumption of housing services: the Gary experiment. J Hum Resour. 1979;14(4):496. https://doi.org/10.2307/145320.

50. Salkind NJ, Haskins R. Negative income tax: the impact on children from low-income families. J Fam Issues. 1982;3(2):165-80. https://doi.org/10.1177/ 019251382003002003

51. Widerquist K. A failure to communicate: what (if anything) can we learn from the negative income tax experiments? J Socio Econ. 2005;34(1):49-81. Available from: https://www.scopus.com/inward/record.uri?eid=2-s2.0-11 044227835\&partnerlD=40\&md5=e0135a0d8994599a6be7c50fcfoffef1. https:// doi.org/10.1016/j.socec.2004.09.050.

52. Spiegelman RG, Yaeger KE. The Seattle and Denver income maintenance experiments: overview. J Hum Resour. 1980;15(4):463. https://doi.org/10.23 07/145397.

53. SEWA BHARAT. A little more, how much it is ... piloting basic income transfers in Madhya Pradesh, India. New Delhi; 2014.

54. Kangas O, Jauhiainen S, Simanainen M, Ylikännö M. The Basic Income Experiment 2017-2018 in Finland: Preliminary Results. 2019 [cited 2020 Jun 9]. Available from: https://julkaisut.valtioneuvosto.fi/bitstream/handle/10024/ 161361/Report_The Basic Income Experiment 20172018 in Finland. pdf? sequence $=1$ \&isAllowed $=\mathrm{y}$.

55. Calnitsky D. "More Normal than welfare": the Mincome experiment, Stigma, and Community Experience. Canadian Sociological Association. 2016;53(1):26-71.

56. Greenberg D, Halsey $H$. Systematic misreporting and effects of income maintenance experiments on work effort: evidence from the Seattle-Denver experiment. J Labor Econ. 1983;1(4):380-407. https://doi.org/10.1086/298019.

57. Metcalf BCE. Making Inferences from Controlled Income Maintenance Experiments. Am Econ Rev. 1973;63(3):478-83. 
58. Keeley MC. Migration as consumption: the impact of alternative negative income tax program. Res Popul Econ. 1980;2:401-32.

59. Keeley MC. The effect of a negative income tax on migration. J Hum Resour. 1980;15(4):695-706. https://doi.org/10.2307/145408.

60. Heffernan J. Impact of a negative income tax on awareness of social services. Soc Work Res Abstr. 1977;13(2):17-23 Available from: http://ovidsp. ovid.com/ovidweb.cgi? T=JS\&CSC=Y\&NEWS=N\&PAGE=fulltext\&D= swab\&AN=906.

61. Johnson WR. The effect of a negative income tax on risk-taking in the labor market. Econ Inq. 1980;18(3):395.

62. Neuberg LG. Distorted transmission: a case study in the diffusion of social "scientific" research. Theory Soc. 1988;17(Jul 88):487-525.

63. Kehrer BH, Wolin CM. Impact of income maintenance on low birth weight: evidence from the Gary experiment. J Hum Resour. 1979;14(4):434-62. https://doi.org/10.2307/145316.

64. Forget EL. New questions, new data, old interventions: the health effects of a guaranteed annual income. Prev Med (Baltim). 2013;57(6):925-8. https:// doi.org/10.1016/j.ypmed.2013.05.029.

65. Greenberg D, Moffitt R, Friedmann J. Underreporting and experimental effects on work effort: evidence from the Gary income maintenance experiment. Rev Econ Stat. 1981 Nov;63(4):581. https://doi.org/10.2307/193 5854.

66. Maynard RA. The Effects of the Rural Income Maintenance Experiment on the School Performance of Children. Am Econ Rev. 1977;67:370-5 [cited 2020 Jun 10]. Available from: https://www.jstor.org/stable/1815932.

67. Murray MC, Pateman C. Basic income worldwide: horizons of reform [Internet]. International political economy series. Houndmills, Basingstoke, Hampshire: Palgrave Macmillan; 2012. p. 83-96.

68. Burtless $\mathrm{G}$, Greenberg D. Inappropriate comparisons as a basis for policy: two recent examples from the social experiments. J Public Policy. 1981;1(3): 381-99. Available from: https://www.scopus.com/inward/record.uri?eid=2-s2 0-84971150777\&partnerlD=40\&md5=241c001c0ef7a1f740ad58aceb913172. https://doi.org/10.1017/S0143814X00001677.

69. Bishop $\mathrm{JH}$. Jobs, cash transfers and marital instability: a review and synthesis of the evidence. J Hum Resour. 1980;15(3):301-34 Available from: http:// ovidsp.ovid.com/ovidweb.cgi? T=JS\&CSC $=$ Y\&NEWS=N\&PAGE=fulltext\&D= swab\&AN=6694

70. Groeneveld LP, Tuma NB, Hannan MT. The effects of negative income tax programs on marital dissolution. J Hum Resour. 1980;15(4):654-75. https:// doi.org/10.2307/145406.

71. Moffitt RA. The negative income tax: would it discourage work? Mon Labor Rev. 1981;104:23-7. Available from: http://search.ebscohost.com/login.a spx?direct=true\&db=buh\&AN=6003207\&site=bsi-live.

72. Cain GG, Wissoker DA. A Reanalyis of marital stability in the Seattle-Denver income-maintenance experiment. Am J Sociol. 1990;95(5):1235-69. https:// doi.org/10.1086/229428.

73. Baumol WJ. An overview of the results on consumption, health, and social behaviour. J Hum Resour. 1974;9(2):253-264.

74. Ashenfelter O, Plant MW. Nonparametric estimates of the labor-supply effects of negative income tax programs. J Labor Econ. 1990;8(1):S396S415.

75. Moffitt RA, Kehrer KC. The effect of tax and transfer programs on labor supply: the evidence from the income maintenance experiments. Res Labor Econ. 2012;35:59-106. https://doi.org/10.1108/S0147-9121(2012)0000035030.

76. Davala S, Jhabvala R, Mehta SK, Standing G. Basic income: a transformative policy in India. London: Bloomsbury; 2015.

77. Rossi PH, Rosenbaum SW. First negative income tax experiment: a giant forward step. Free Inq Creat Sociol. 1983;11(2):121-8.

78. Osterkamp R. The Basic income Grant pilot project in Namibia: a critical assessment. Basic Income Stud. 2013;8(1):71-91.

79. Widerquist K. A Critical Analysis of Basic Income Experiments for Researchers, Policymakers, and Citizens. 1st ed. A Critical Analysis of Basic Income Experiments for Researchers, Policymakers, and Citizens. Palgrave Pivot; 2018.

80. Calnitsky D. Basic Income and the Pitfalls of Randomization. Contexts. 2019; 18(1):22-9 [cited 2020 Jun 10]. Available from: http://journals.sagepub.com/ doi/10.1177/1536504219830673.

81. Gibson M, Hearty W, Craig P. Potential effects of universal basic income: a scoping review of evidence on impacts and study characteristics. Lancet. 2018 Nov;392:S36. https://doi.org/10.1016/S0140-6736(18)32083-X.

82. Moffitt RA. The negative income tax: would it discourage work? Mon Labour Rev. 1981;104(4):23-7.
83. Spiegelman RG, Yaeger K. Overview: the Seattle and Denver income maintenance experiments. J Hum Resour. 1980;15(4):463-79. https://doi. org/10.2307/145397.

84. Kershaw DN, Fair J. The New Jersey income-maintenance experiment. Watts H, Rees a, editors. Vol. 1. New York: Academic Press; 1976.

85. Dickinson K, Watts HW. The experimental panel data resources at the poverty institute data center. Am Econ Rev. 1975;65(2):263-9.

86. Braveman P, Gottlieb L. The social determinants of health: It's time to consider the causes of the causes. Public Health Rep. 2014;129(SUPPL. 2): 19-31. https://doi.org/10.1177/00333549141291S206.

87. Brodkin EZ, Kaufman A. Policy experiments and poverty politics. Soc Serv Rev. 2000;74(4):507-32. https://doi.org/10.1086/516423.

88. Burtless $\mathrm{G}$. The work response to a guaranteed income: a survey of experimental evidence. Conf Ser, Federal Reserve Bank of Boston. 1986;30: 22-59.

89. Burtless BG, Greenberg D. Inferences concerning labor supply behavior based on limited-duration experiments. Am Econ Rev. 1982;72(3):488-97.

90. Burtless G, Hausman JA. The Effect of Taxation on Labor Supply: Evaluating the Gary Negative Income Tax Experiment. J Polit Econ. 1978;86(6):1103-30.

91. Byrne DM. Some preliminary results of income-maintenance experiments. Nebraska J Econ Bus. 1973;12(4):23.

92. Cain GG., Nicholson W, Mallar CD., Wooldridge J. The labour-supply response of married women, husband present. J Hum Resour. 1974;9(2): 201-222.

93. Arvin BM, Choudhry S. Negative income taxes and household transition dynamics: evidence from the Canadian Mincome experiment. Int J Appl Econ. 2001;9(3):255-84

94. Choudhry SA, Hum DPJ. Graduated work incentives and how they affect marital stability: the Canadian evidence. Appl Econ Lett. 1995;2(10):367-71. https://doi.org/10.1080/758518991.

95. Curry WF. The use of field tests in the making of public policy: comparative case studies. West Virginia University; 1981.

96. Elesh D, Lefcowitz MJ. The effects of the New Jersey Pennsylvania negative income tax experiment on health and health care utilization. J Health Soc Behav. 1977;18(4):391-405. https://doi.org/10.2307/2955347.

97. Forget EL. Abolishing poverty: the history and significance of the north American guaranteed annual income social experiments. Stor Del Pensiero Econ. 2010;1:5-31.

98. Forget EL, Peden AD, Strobel SB. Cash transfers, basic income and community building. Soc Incl. 2013;1(2):84-91. Available from: https://www. scopus.com/inward/record.uri?eid=2-s2.0-84921846815\&partnerlD= 40\&md5=c1b82d05d09aa960f2ad59d4409a4cbc. https://doi.org/10.17645/si. v1i2.113.

99. Hollister RG. The Labor-Supply Response of the Family. J Hum Resour. 1974; 9(2):223 [cited 2020 Jun 10]. Available from: https://www.jstor.org/stable/144 974.

100. Hum DP, Hum D, Choudhry S. Income, work and marital dissolution: Canadian experimental Evidence. J Comp Fam Stud. 1992;23(2):249-65. https://doi.org/10.3138/jcfs.23.2.249

101. Hum D, Simpson W. Income maintenance, work effort, and the Canadian Mincome experiment. Economic Council of Canada; 1991.

102. Hum D, Simpson W. Economic response to a guaranteed annual income: Experience from Canada and the United States. J Labor Econ. 1993;11(1): S263-296.

103. Huston AC. Effects of poverty on children. In: Balter L, Tamis-LeMonda CS, editors. Child psychology: a handbook of contemporary issues [internet]. New York: Psychology Press; 1999. p. 391-411. Available from: https:// psycnet.apa.org/record/1999-04370-018.

104. Kangas O, Jauhiainen S, Simanainen M, Ylikännö M. The basic income experiment 2017-2018 in Finland: Preliminary results. [Internet]. Reports and memorandums of the ministry of social affairs and health. 2019. Available from: http://julkaisut.valtioneuvosto.fi/bitstream/handle/10024/161361/ Report_The Basic Income Experiment 20172018 in Finland.pdf. ISBN:978952-00-4035-2

105. Keeley BMC, Robins PK, Spiegelman RG, West RW. The estimation of labor supply models using experimental data. Am Econ Rev. 1978;68(5):873-87.

106. Keeley MC, Robins PK, Spiegelman RG, West RW. The labor-supply effects and costs of alternative negative income tax programs. J Hum Resour. 1978. 13(1):3-36. https://doi.org/10.2307/145299.

107. Keeley M, Robins P. Work Incentives and the Negative Income Tax. Challenge. 1979;22(1):52-5 [cited 2020 Jun 10]. 
108. Keeley MC. The effects of negative income tax programs on fertility. J Hum Resour. 1980;15(4):675-94. https://doi.org/10.2307/145407.

109. Keeley MC. The effects of experimental negative income tax programs on marital dissolution : evidence from the Seattle and Denver income maintenance experiments. Int Econ Rev (Philadelphia). 1987;28(1):241-57. https://doi.org/10.2307/2526870.

110. Kerachsky SH. Labor supply decisions of farm families. Am J Agric Econ. 1977 Dec;59(5):869-76. https://doi.org/10.2307/1239851.

111. Kershaw DN. A negative-income-tax experiment. Sci Am. 1972 Oct;227(4): 19-25. https://doi.org/10.1038/scientificamerican1072-19.

112. Levine RA, Watts H, Hollister R, Williams W, O'Connor A, Widerquist K. A Retrospective on the Negative Income Tax Experiments: Looking Back at the Most Innovative Field Studies in Social Policy. In: The Ethics and Economics of the Basic Income Guarantee; 2005. p. 95-106. Available from: https://works.bepress.com/widerquist/14/.

113. Maynard RA, Murnane RJ. The effects of the rural income maintenance experiment on the school performance of children. J Hum Resour. 1979; 14(4):463-76. Available from: http://search.ebscohost.com/login.aspx?direct= true\&db=buh\&AN=4511673\&site=ehost-live. https://doi.org/10.2307/145317.

114. McDonald JF, Stephenson SP Jr. The effect of income maintenance on the school-enrollment and labor-supply decisions of teenagers. J Hum Resour. 1979:14(4):488.

115. Moffitt RA. The labor supply response in the Gary Experiment. J Hum Resour. 1979;14(4):477.

116. Munnell AH, Burtless G, Cain G. Lessons from the income maintenance experiments. In: Munnell AH, editor. Economic Research Conference Series 30 [Internet]. Federal Reserve Bank of Boston and The Brookings Institute; 1987. p. 1-94.

117. O'Connor JF, Madden JP. The negative income tax and the quality of dietary intake. J Hum Resour J Hum Resour. 1979;14(4):507-17. https://doi. org/10.2307/145321.

118. Robins PK. A comparison of the labor supply findings from the four negative income tax experiments. J Hum Resour. 1985;20(4):567-82. Available from: http://search.ebscohost.com/login.aspx?direct=true\&db=ssa \&AN=508147570\&site=ehost-live. https://doi.org/10.2307/145685.

119. Robins PK, Tuma NB, Yaeger KE. The Seattle and Denver income maintenance experiments. J Hum Resour. 1980;15(4):545-73. https://doi. org/10.2307/145401.

120. Robins PK, West RW. Sample attrition and labor supply response in experimental panel data: a study of alternative correction procedures. J Bus Econ Stat. 1986;4(3):329-38.

121. Ross HL. An experimental study of the negative income tax. Massachusetts Institute of Technology; 1970. Available from: http://dspace.mit.edu/ha ndle/1721.1/13874? show=full.

122. Standing G. Why Basic Income's emancipatory value exceeds its monetary value. Basic Income Stud. 2015;10(2):193-223.

123. Stephens M. Are there treatment duration differences in the Seattle and Denver income maintenance experiments? B E J Econom Anal Policy. 2007; 7(1):1-41.

124. Watts H. Graduated works incentives: an experiment in negative taxation. Am Econ Rev. 1969 May;59(2):463-72.

125. Weiss Y, Hall A, Dong F. The Seattle and Denver Income Maintenance Experiments: The Effect of Price and Income on Investment in Schooling. J Hum Resour. 1980;15(4):611.

126. West RW. Effects on wage rates: an interim analysis. J Hum Resour. 1980; 15(4):641. https://doi.org/10.2307/145405.

127. West RW. The effects on the labor supply of young nonheads. J Hum Resour. 1980;15(4):574. https://doi.org/10.2307/145402.

128. Widerquist $K$. What (if anything) can we learn from the Negative Income Tax experiments? In: Widerquist $K$, Noguera JA, Vanderborght $Y$, de Wispelaere $J d$, editors. Basic income: an anthology of contemporary research. Chichester: Wiley Subscription Services, Inc., A Wiley Company; 2013. p. 216-29.

129. Wright SR, Wright JD. Income maintenance and work behavior. Soc Policy. 1975;6(2):24-32.

\section{Publisher's Note}

Springer Nature remains neutral with regard to jurisdictional claims in published maps and institutional affiliations.

Ready to submit your research? Choose BMC and benefit from:

- fast, convenient online submission

- thorough peer review by experienced researchers in your field

- rapid publication on acceptance

- support for research data, including large and complex data types

- gold Open Access which fosters wider collaboration and increased citations

- maximum visibility for your research: over $100 \mathrm{M}$ website views per year

At $\mathrm{BMC}$, research is always in progress.

Learn more biomedcentral.com/submissions 